



\section{Antibiotic Residues and Resistance in the Environment}

M.G. Pikkemaat, H. Yassin, H.J. van der Fels-Klerx and B.J.A. Berendsen 
Pikkemaat, M.G., H. Yassin, H.J. van der Fels-Klerx and B.J.A. Berendsen, 2016. Antibiotic Residues and Resistance in the Environment. Wageningen, RIKILT Wageningen UR (University \& Research centre), RIKILT report 2016.009. 32 pp.; 1 fig.; 0 tab.; 179 ref.

Project number: 124.73 .148 .01

BAS-code: WOT-02-003-065

Project title: Antibiotic research

Project leader: Bjorn J.A. Berendsen

(c) 2016 RIKILT Wageningen UR

The client is allowed to publish or distribute the full report to third parties. Without prior written permission from RIKILT Wageningen UR it is not allowed to:

a) publish parts of this report;

b) use this report or title of this report in conducting legal procedures, for advertising, acquisition or other commercial purposes;

c) use the name of RIKILT Wageningen UR other than as author of this report.

P.O. Box 230, 6700 AA Wageningen, The Netherlands, T +31 (0)317 4802 56, E info.RIKILT@wur.nl, www.wageningenUR.nl/en/rikilt. RIKILT is part of Wageningen UR (University \& Research centre).

This report from RIKILT Wageningen UR has been produced with the utmost care. However, RIKILT does not accept liability for any claims based on the contents of this report.

This report can be downloaded for free at http://dx.doi.org/10.18174/388253 or at www.wageningenUR.nl/en/rikilt (under RIKILT publications).

RIKILT report 2016.009

Distribution list:

- Drs. Lesuis, R, NVWA, Utrecht

- Dr. Thomas, M.E., NVWA, Utrecht

- Dr. Raap, J.J., NVWA, Utrecht 


\section{Contents}

$\begin{array}{ll}\text { Summary } & 5\end{array}$

1

$\begin{array}{ll}\text { Introduction } & \mathbf{7}\end{array}$

2

$\begin{array}{ll}\text { Antibiotic residues and resistance in animal production } & \mathbf{8}\end{array}$

2.1 Antibiotic resistance in livestock $\quad 8$

2.2 Antibiotic use in animal production $\quad 9$

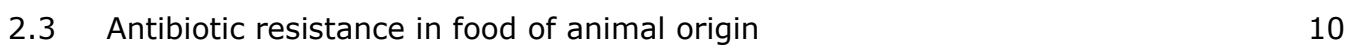

3 Environmental fate of antibiotic residues associated with veterinary treatment

3.1 Environmental exposure of antibiotics through animal production 11

3.1.1 Animal manure 11

$\begin{array}{ll}3.1 .2 \text { Aquaculture } & 11\end{array}$

3.2 Persistence of antibiotics in the environment 12

3.2.1 Sorption $\quad 12$

3.2.2 Degradation (transformation) 13

$\begin{array}{lll}3.3 & \text { Persistence of different types of antibiotics } & 13\end{array}$

3.3.1 Tetracyclines 13

3.3.2 Macrolides 14

$\begin{array}{ll}3.3 .3 \text { Fluoroquinolones } & 15\end{array}$

$\begin{array}{ll}3.3 .4 \text { Beta-lactams } & 15\end{array}$

$\begin{array}{ll}3.3 .5 & \text { Sulfonamides }\end{array}$

$\begin{array}{ll}3.3 .6 & \text { Aminoglycosides } \\ & 16\end{array}$

4 Consequences of antibiotic residues in the environment $\quad 17$

$\begin{array}{lll}4.1 & \text { Effect on microbial communities } & 17\end{array}$

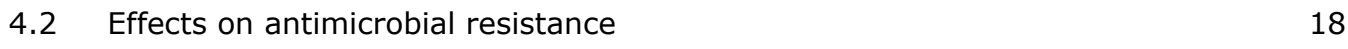

$\begin{array}{llr}5 & \text { Discussion } & 19\end{array}$

$\begin{array}{lrr}6 & \text { Conclusions } & 21\end{array}$

$7 \quad$ Acknowlegement $\quad 22$

$\begin{array}{ll}\text { References } & 23\end{array}$ 



\section{Summary}

Antibiotic usage has benefited the animal industry and helped providing affordable animal proteins to the growing human population. However, since extensive use of antibiotics results in the inhibition of susceptible organisms while selecting for the resistant ones, agricultural use is contributing substantially to the emergence and spread of antibiotic resistance in the environment.

So far, scientific focus has predominantly been on the emergence and spread of resistant bacteria and genes into the environment as a result of veterinary treatment, in particular through manure but also through food products and direct animal contact. However, environmental contamination with antibiotic residues could also be an important factor in the selection and dissemination of antibiotic resistant bacteria.

The persistence of antibiotics in the environment depends on factors like soil type and climate, but also on physical-chemical characteristics of the different types of antibiotics. Monitoring studies showed that substantial concentrations of antibiotic residues can occur in soil and water, in particular at locations close to intensive animal farming.

Little is known about the concentrations that will exert selective pressure on environmental microorganisms and promote persistence or even enrichment of the environmental resistance gene pool. Traditionally, it was assumed that resistance is only induced at concentrations above the minimum inhibitory concentration (MIC). However, recently, evidence is accumulating that selective environments may occur at concentrations down to several hundred-folds below the MIC.

However, for most of the antibiotics and environmental conditions, the minimal threshold concentrations that will induce or support propagation of antibiotic resistance in environmental microbes are still undefined. Therefore, more research is needed into the relationship between the concentrations of antibiotic residues in the environment and the prevalence and persistency of environmental antibiotic resistance. First, additional research is needed to determine what antibiotic concentrations still exert pressure on bacteria and can cause persistence or enrichment of resistant bacteria. Furthermore, the fate of antibiotics in the main reservoirs (manure, soil, water) should be studied, including antimicrobially active metabolites and their bioavailability. Finally, transmission of antibiotic compounds between reservoirs should be studied to identify the main reservoirs of interest and define intervening measures. 


\section{Introduction}

Antibiotics are an essential medicine for treatment of certain types of animal and human disease. The use of antibiotics inevitably provokes the development of antibiotic resistant bacteria. Resistance determinants were already proven to exist in the environment prior to the introduction of antibiotics for therapeutic purposes (Bhullar, 2012; D'Costa, 2011), however, the diversity and dispersal of resistant organisms has increased dramatically during the past few decades (Levy, 2002).

Consequently, antibiotic resistance has become a serious and growing threat to modern medicine, and emerged as one of the leading health concerns of the $21^{\text {st }}$ century (WHO, 2014). It has been estimated that a continued rise in antimicrobial resistance (AMR) by 2050 will lead to 10 million people dying annually, and a reduction of 2 to $3.5 \%$ in Gross Domestic Product (GDP) (http://amrreview.org/). Also in Europe, the problem of antimicrobial resistance has been assigned as a high priority topic in the coming years (EC, 2015).

Antimicrobial resistance evolved with the increased number, volume and diversity of antimicrobial applications used in humans and animals (Barbosa and Levy, 2000; Levy, 2002; Kumar, 2005a). The use of antibiotics in animal production contributes significantly to the development and spread of antibiotic resistance in animals and food of animal origin (EFSA 2015). In particular, the widespread sub-therapeutic use of antibiotics as animal growth promoter (AGP) was found to favor the selection, spread, and the establishment of stable resistant strains in the environment (van den Bogaard, 1999; Levy, 2002; Andremont, 2003; Kumar, 2005a) and is, therefore, no longer accepted within the EU (EC 2003).

Effects of the use of antibiotics in animal production on antibiotic resistance development, as well as the origin and the different transmission routes by which antibiotic residues enter the environment, have been extensively studied. However, research on the effect of the presence of antibiotic residues in the environment has received little attention so far. To date, little is understood on the relations between the levels of antibiotic residues that enter the environment and antibiotic resistance development and persistence in the environment.

The objective of this study was to review literature on the dissemination of antibiotic residues originating from animal production into the environment and the effect of these residues on persistence and enrichment of antibiotic resistance to identify knowledge gaps and needs for future research. 


\section{$2 \quad$ Antibiotic residues and resistance in animal production}

\subsection{Antibiotic resistance in livestock}

Whenever an animal receives a dose of antibiotics, there is an opportunity for bacteria to develop resistance to the antibiotic. Bacteria may exhibit two types of resistance: intrinsic and acquired resistance. Intrinsic resistance refers to bacteria's natural characteristics rendering them immune to the antibiotic's action mechanism. This is a natural (intrinsic) property to all members of a species and is unrelated to the over/misuse of antibiotics. Acquired resistance occurs when a particular microorganism obtains the ability to resist the activity of a particular antimicrobial agent to which it was previously susceptible, and becomes able to proliferate and spread under the selective pressure of the use of that agent. In this process, bacteria resist antibiotics by taking on new characteristics. Bacteria can acquire resistance in two ways: through vertical gene transfer i.e. by mutations that alter the pre-existing DNA of the cell, causing changes to the gene(s) already present. Alternatively, bacteria can acquire resistance through horizontal gene transfer i.e. the acquisition of new genetic material, originating from a bacterium that is already resistant, or from the environment. In this case the existing genome is expanded with genes that are new to the cell. The common horizontal gene transfer mechanisms used by bacteria are: conjugation, transformation or transduction (Aminov, 2011).

Several common surviving mechanisms that are used by bacteria to resist antibiotics can be distinguished: 1) increased expression of efflux pumps, 2) permeability changes in the bacterial cell membrane which limit the amount of antimicrobial entering into the bacterium, 3) physical modification / inactivation of the antimicrobial agent, 4) enzymatic inactivation of the antibiotic, and 5) modification of the molecular binding sites (O'Brien, 2002; McDermott, 2003; Alekshun and Levy, 2007).

The incidence of antibiotic resistant bacteria in farm animals is depending on multiple factors including the amounts of antibiotics used, type of antibiotics, administration route, and species of animals (Guillemot, 1998; Levy, 2001; Catry, 2003). There is clear evidence on the relationship between the use of antibiotics and increased resistance development in farm animal production (Endtz, 1991; Klare, 1995; Bager, 1997; Dunlop, 1998; Aarestrup, 1999; Kruse, 1999). A prominent example is the rapid emergence of fluoroquinolone resistant bacteria from poultry in the 1990's, soon after the introduction of these antibiotics for treatment of poultry (Jacobs-Reitsma, 1994). In the Unites States the increasing prevalence of fluoroquinolone resistant Campylobacter in humans prompted the US Food and Drug Administration in 2005 to ban the use of enrofloxacin in poultry. Fluoroquinolones are considered "critically" or "very" important to human medicine (Category I) by the World Health Organization (WHO, 2007). Nevertheless, they are still allowed for veterinary use in Europe.

Antibiotic resistance occurs in zoonotic pathogens such as Salmonella and Campylobacter spp., as well as commensal bacteria. Commensal flora plays an important role in physiological and metabolic processes as well as in the development of the animal's immune system (Ivanov and Honda, 2012). In particular the intestine contains incredible numbers of bacteria that are exposed to resistance provoking antibiotic concentrations during the treatment of an infection or the application of growth promotors. Subsequently, forms an effective and important reservoir for antibiotic resistance (Acar and Moulin, 2006). Not surprisingly, resistance prevalence and profiles of commensal organisms are very similar to their zoonotic counterparts (MARAN, 2015). A particular worrying trend is the increasing occurrence of multidrug resistance. For example, in 2012 more than $60 \%$ of the commensal E. coli strains from broiler chickens in the Netherlands were found to show resistance to two or more classes of antibiotics (MARAN, 2015).

Antimicrobial resistance formed in livestock may be transmitted to humans. Livestock associated MRSA is widely found in farmers and veterinarians (Voss, 2005; Wulf, 2008). Also the significance of 
livestock as a reservoir for ESBL (Extended Spectrum Beta-Lactamase) -producing bacteria is increasingly being recognized as a threat to human health care (Dohmen, 2015).

\subsection{Antibiotic use in animal production}

In animal production antibiotics are used for therapy, prevention of bacterial diseases, or as performance enhancers. To fight infections, animals may be treated individually, but in particular situations where individual treatment is not feasible, it is common to treat entire groups by medicating through feed or water. Therapeutic treatment relies on generating an active antibiotic concentration that exceeds the minimal inhibitory concentration (MIC) of the pathogen for an effective time period. Veterinary therapy for infection is mainly empiric, guided by the clinical presentation and not based on pathogenic species identification. The type and amount of antibiotics administered to animals varies between animal species. In the Netherlands, the major veterinary antimicrobials used, are tetracyclines, trimethoprim/sulfonamides combinations and penicillins, and to a lesser extent macrolides and aminoglycosides (MARAN 2015). Registered products are available from a publicly accessible database: www.diergeneesmiddeleninformatiebank.nl.

Antibiotic treatment of farm animals may result in the presence of antibiotic residues in foodstuffs of animal origin. In order to protect public health, the European commission has established legislation concerning the establishment of acceptable residue limits of pharmacologically active substances in foodstuffs of animal origin (REGULATION (EC) No 470/2009, originally Council Regulation (EEC) No 2377/90). "Maximum residue limits (MRLs) should be established in a safety assessment, taking into account toxicological risks, environmental contamination, as well as the microbiological and pharmacological effects of residues" (EC, 2009). Establishment of the withdrawal period, the period necessary between the last administration of a veterinary medicinal product and the production of foodstuffs from the animal, in order to ensure that the animal products do not contain residues in excess of the MRLs, is an essential part of the marketing authorization of veterinary medicinal products (Directive 2001/82/EC) (EC, 2001). The MRLs for antibiotic residues can be found in Commission Regulation (EU) No 37/2010 (EC, 2010). Compliance with these MRLs is monitored within the National Residue Monitoring Plan, according to an EU wide harmonized program with respect to sampling frequency and range of substances and matrices to be tested (EC, 1996). Results of these National Residue Monitoring Plans are published annually in the Commission Staff Working Paper on the implementation of national residue monitoring plans in the Member States (http://ec.europa.eu/food/food/chemicalsafety/residues/control_en.htm). These data show that the percentage of non-compliant results for antibiotic residues in food products is very low. Note that methods applied are usually designed to discriminate compliant samples from MRL violations and thus, residues present below the established MRLs might not be detected.

MRLs are derived from toxicologically or microbiologically based Acceptable Daily Intakes (ADI), and in case of the antibiotics usually the microbiological ADI prevails. The procedure includes the in vitro testing of bacteria representative of the human gut flora and the ADI is calculated based on the observed MIC values.

This does not imply that MRL concentrations by definition do not have a physiological effect on bacteria. In milk concentrations as low as $6 \mu \mathrm{g} \mathrm{kg}^{-1}$ penicillin considerably inhibit the growth of starter cultures used for fermentative dairy production. For this reason the MRL for penicillins (penicillin G, amoxicillin, ampicillin) was set at $4 \mu \mathrm{g} \mathrm{kg}^{-1}$, but it should be noted that concentrations as low as $2 \mu \mathrm{g} \mathrm{kg}^{-1}$ are still capable of inhibiting the growth of the common test organism Bacillus stearothermophilus. Remarkably, the MRLs in edible tissue were set at a higher level $\left(50 \mu \mathrm{gg}^{-1}\right)$ matching the sensitivity of the EU four plate test (EMA, 2008). Additionally, exposure of Staphylococcus aureus to the MRL levels of ampicillin, dihydrostreptomycin, erythromycin, neomycin, oxytetracycline, and sulfamethazine in milk was shown to have a strong potential for the selection of antibiotic resistant bacterial populations under these conditions (Brady, 1993).

Antibiotics have also been used as antimicrobial growth promotors (AGPs), applying them in feed or water at a sub-therapeutic dose for a prolonged period, in order to improve feed efficiency and 
promote production (McEwen and Fedorka-Cray, 2002). However, the associated risk of developing bacterial resistance to the antibiotics, compromising the treatment of human as well as animal infections, made the European Commission decide to phase-out and eventually ban the marketing and use of antibiotics as growth promoters in animal feed as of the first of January 2006 (EC Regulation No. 1831/2003, EC, 2003). It should be noted, however, that in many parts of the world the use of AGPs is still common practice.

Even though antibiotics are used extensively in animal production, reliable data on the exact quantity, dose and frequency of application are limited. The amount of antibiotics administered to animals varies widely between animal species and countries. In European countries, total use of antibiotics has been estimated to range from 20 to $188 \mathrm{mg} \mathrm{kg}^{-1}$ of animal produced (Grave, 2010). Recent estimations suggest that the global average use of antimicrobials per kilogram of animal produced in 2010 was $45 \mathrm{mg} \mathrm{kg}^{-1}, 148 \mathrm{mg} \mathrm{kg}^{-1}$, and $172 \mathrm{mg} \mathrm{kg}^{-1}$ for cattle, chicken, and pigs, respectively (Van Boeckel, 2015). It is foreseen that this global use of antimicrobials for livestock production will increase another 67\%, from 63 tons to 105 tons by 2030 (Van Boeckel, 2015). This increase is mainly attributable to low- and middle income countries that have to meet a growing demand for animal protein. In Europe, on the other hand, there is a growing awareness of the risks associated with unlimited antibiotic use in livestock production. Active policy on the reduction of veterinary antibiotic consumption in the Netherlands resulted in a 63\% reduction of the sales of antibiotics between 2007 and 2013 (MARAN, 2015; Speksnijder, 2015).

\subsection{Antibiotic resistance in food of animal origin}

In parallel with the increasing incidence of antibiotic resistant bacteria in farm animals, resistant bacteria are also more and more frequently found on food products of animal origin (Johnson, 2005; Aarestrup, 2008; Overdevest, 2011; Tham, 2012) and even on vegetables (Reuland, 2014; Hoek, 2015). In the Netherlands the use of fluoroquinolones caused a staggering increase in the prevalence of ciprofloxacin resistant Salmonella isolates from retail poultry meat; between 2000 and 2007 the prevalence rose from 0 to $60 \%$ (MARAN 2015). Alarming prevalence data were also reported for ESBL producing micro-organisms in retail poultry in the Netherlands: $100 \%$ on conventional and $84 \%$ on organic muscle samples (Cohen Stuart, 2012). The presence of ESBL producing bacteria in meat of other animal species however, was found to be considerably lower (MARAN, 2015).

Despite the previously mentioned correlation between the emergence of fluoroquinolone resistance in poultry and human Campylobacter isolates, the risk of resistant bacteria being transmitted to people through food is generally believed to be low (Food Safety authority of Ireland, 2015), although reliable data are missing. Adherence to kitchen hygiene rules in food preparation generally minimizes the risk, since the risk of colonization and infection of people via food depends to a large extent on the quantity of these bacteria in the food. Raw food products obviously hold a more substantial risk for transfer of bacteria and thus also antimicrobial resistance. Besides the direct transfer of resistant bacteria, intact DNA coding for resistant might be transmitted through foods, and the potential for uptake by bacteria in the human gut is uncertain (EFSA, 2008). 


\section{Environmental fate of antibiotic residues associated with veterinary treatment}

\subsection{Environmental exposure of antibiotics through animal production}

\subsubsection{Animal manure}

The use of antibiotics in veterinary treatment contributes to environmental exposure of drug residues mainly through animal manure. Most antibiotics are absorbed by the body after administration, and can be metabolized. Elimination of the parent drug and/or metabolites occurs essentially through the urine and/or feces. Antibiotics with poor oral absorption (e.g. aminoglycosides and colistin, applied for intestinal infections) will exit the animal through the feces. The extent to which an antibiotic is metabolized is an important factor in environmental exposure, since for most compounds the metabolites show reduced or no antibacterial activity. A notable exception to this is enrofloxacin, which is metabolized in vivo to ciprofloxacin, which is a critically important antibiotic for human medicine. For some antibiotics, the metabolites may also revert back into the parent compound and regain antibacterial activity upon release in the environment. For example, sulfonamides will be excreted partially as acetic acid conjugates, which can be converted back into their parent compounds (Boxall, 2002; Heuer, 2008). The extent of in vivo metabolism of an antibiotic depends on the mode of application, the type of animal, and the age of the animal (Nouws, 1992; Toutain, 2010).

Reports on antibiotic residue concentrations in manure show large variations. Concentrations in manure depend on individual/group treatment (potential dilution), duration of the treatment and the moment of sampling related to treatment period. The highest and most frequently reported concentrations of antibiotic residues in manure belong to the tetracycline group of antibiotics. The reported levels regularly exceed $100 \mathrm{mg} \mathrm{kg-1}$ (Massé, 2014), with extremes up to $764 \mathrm{mg} \mathrm{kg-1} \mathrm{chlorotetracycline} \mathrm{in} \mathrm{swine}$ manure (Pan, 2011). Observed concentrations for sulfonamides are also considerable: Martinez-Carballo (2007) reported concentrations level up to $20 \mathrm{mg} \mathrm{kg-1}$ for sulfadimidine and up to $91 \mathrm{mg} \mathrm{kg-1}$ for sulfadiazine (Martinez-Carballo, 2007). Reports on fluoroquinolone concentrations in manure are relatively scarce, however, Zhao et al. (2010) showed that also this type of antibiotic animal treatment may lead to high residue concentrations in manure; residue concentrations up to $45 \mathrm{mg} \mathrm{kg-1}$ ciprofloxacin, $1420 \mathrm{mg} \mathrm{kg-1} \mathrm{enrofloxacin,} 99 \mathrm{mg} \mathrm{kg}-1$ fleroxacin and $225 \mathrm{mg} \mathrm{kg}-1$ norfloxacin were observed. Data for macrolide antibiotics mainly concern tylosin, with maximum concentrations of $8.1 \mathrm{mg}$ kg-1 (Dolliver, 2008) and $7 \mathrm{mg} \mathrm{kg-1} \mathrm{(Berendsen,} \mathrm{2015).} \mathrm{The} \mathrm{latter} \mathrm{author} \mathrm{also} \mathrm{found} \mathrm{tilmicosin,} \mathrm{tiamulin}$ and lincomycin in their study, levels for these residues were in the $\mu \mathrm{g} \mathrm{kg-1}$ area. Penicillins show poor stability in manure (Berendsen, 2015), possibly due to the presence of ESBL-producing bacteria, explaining the absence of surveillance results for this antibiotic group. For aminoglycosides data on the occurrence in manure are lacking, but this might also be attributable to the fact that this residue group is difficult to include in routine LC/MS methods for antibiotic analysis.

\subsubsection{Aquaculture}

Another important veterinary route for the dissemination of antibiotic residues into the environment is through aquaculture or fish farming. Although hardly significant in the Netherlands (EZ, 2015), globally aquaculture contributes considerably to the environmental exposure to antibiotic residues. Aquaculture is the fastest growing animal food producing sector, and aquaculture is estimated to account for almost half of total food-fish supply (FAO, 2014).

In aquaculture, antibiotics are usually administered as medicated feed but also through a therapeutic bath, yielding environmental exposure through water contamination and contamination of the sediment in the pond by fish excrements and unused feed. The virtually unrestricted application of 
quinolones and many other antibiotics in aquaculture in countries with growing aquaculture industries such as Chile, China and Vietnam, is a major concern (Cabello, 2004; Thuy, 2011) and has been reported to lead to alarming concentrations of antibiotics in the areas surrounding the aquaculture sites (Tuan, 2004).

\subsection{Persistence of antibiotics in the environment}

Considerable residual concentrations of antibiotics in agricultural soils have been reported (ThieleBruhn, 2003), ranging from 450 to $900 \mu \mathrm{g} \mathrm{kg}^{-1}$ for tetracyclines (Winckler and Grafe, 2000), from 13 to $67 \mu \mathrm{g} \mathrm{kg}^{-1}$ for macrolides and from 6 to $52 \mu \mathrm{g} \mathrm{kg}^{-1}$ for fluoroquinolones (Schüller, 1998). In soils under conventional landfarming fertilized with manure, average concentrations of up to $199 \mu \mathrm{kg}^{-1}$ tetracycline, $7 \mu \mathrm{g} \mathrm{kg}^{-1}$ chlortetracycline (Hamscher, 2002), and $11 \mu \mathrm{g} \mathrm{kg}^{-1}$ sulfadimidine (Höper, 2002) were found. German surface water samples were frequently contaminated with sulfonamides and macrolides and, to a lesser extent with fluoroquinolones (Christian, 2003). Observed concentrations, however, were low $\left(<0.2 \mu \mathrm{g} \mathrm{L}^{-1}\right)$. Much higher concentrations were reported in a Chinese study that investigated the presence of several antibiotic residues in animal wastewater and surface water around farms. In this study, the maximum concentrations ranged between $0.63 \mu \mathrm{g} \mathrm{L}^{-1}$ and $211 \mu \mathrm{g} \mathrm{L}^{-1}$ for different sulfonamides, and between $3.67 \mu \mathrm{g} \mathrm{L}^{-1}$ and $72.9 \mu \mathrm{g} \mathrm{L}^{-1}$ for tetracyclines (Wei, 2011).

When antibiotic residues enter the environment, the main processes determining their persistence are sorption to organic particles and degradation/ transformation (Kümmerer, 2004). Both processes depend on a number of different factors: physical-chemical properties of the residue, characteristics of the soil, and climatic factors, such as temperature, rainfall, and humidity (Kemper, 2008).

\subsubsection{Sorption}

The mobility and transport of antibiotics in the environment depends on their sorption behavior. Sorption of antibiotics to the soil can reduce their mobility and, consequently, the potential leaching to ground and surface water. But sorption can also affect reactivity, and bioavailability for microbial degradation (Jensen, 2001). Sorption of chemicals is typically estimated by the soil-water distribution coefficient (Kd) (Wegst-Uhrich, 2014). The soil parameters that are believed most important for adsorption are: organic carbon content, clay content and soil texture, and pH for ionisable compounds (OECD, 2000). Sorption models generally assume that the soil-water distribution coefficient is related to the organic carbon content of the soil material: $\mathrm{Kd}=\mathrm{Koc} \times \mathrm{foc}$, in which $\mathrm{Koc}$ is the organic carbon-normalized partition coefficient, foc the organic carbon content. The Koc value can in turn be calculated from the octanolwater partition coefficient, Kow. Kow, however, only reflects hydrophobic interactions and does not accurately account for other physical and chemical properties of the antibiotic residue like electrostatic interactions, hydrogen bonding and cation-exchange, which may vary significantly with changes in $\mathrm{pH}$, organic matter, and ionic strength. For most antibiotics the acid dissociation constant value ( $p K a)$ is in the range of soil $\mathrm{pH}$ values, indicating that their protonation/ionization state depends on the $\mathrm{pH}$ value of the soil type in which they reside (Tolls, 2001; Thiele-Bruhn, 2003). So, both the soil characteristics, and the physicochemical properties of the antibiotics residues play an essential role in the sorption to soils and sediments (Tolls, 2001; Sassman and Lee, 2005; Sarmah, 2006).

Obviously, considering the potential variety in all of the above mentioned factors, the degree to which antibiotics may adsorb to soil varies widely. Sorption coefficients of antibiotics have been reported to range from as low as $0.61 \mathrm{~L} \mathrm{~kg}^{-1}$ to as high as $6000 \mathrm{~L} \mathrm{~kg}^{-1}$ (Boxall, 2004). The application of manure increases the organic carbon content and is therefore an important practice influencing the sorption potential of the soil. The sorption coefficient of sulfadiazine, for example, was shown to increase 10 -fold as a result of manure application (Sukul, 2008). Generally it is assumed that the sorption potential for tetracyclines is high and also macrolides and fluoroquinolones show significant sorption, while sulfonamides exhibit only weak sorption to the soil (Huang, 2001; Figueroa-Diva, 2010). For aminoglycosides and beta-lactams reliable data are lacking. Detailed reviews on the sorption behavior of several antibiotics are available (Tolls, 2001; Thiele-Bruhn, 2003; Wegst-Uhrich, 2014). 


\subsubsection{Degradation (transformation)}

Degradation of antibiotics in soil can occur through abiotic and biotic processes. Hydrolysis is generally considered an important abiotic degradation pathway. Beta-lactams, macrolides and sulfonamides are theoretically susceptible to hydrolysis. However, in environmental conditions only $\beta$-lactams are hydrolyzed at a significant rate (Hou and Poole, 1969), since hydrolysis of macrolides and sulfonamides at neutral $\mathrm{pH}$ range is very slow (Volmer and Hui, 1998). Another important abiotic degradation process is photo-degradation. Photo-degradation may contribute to the overall reduction of concentrations of residues in particular aquatic environments and when antibiotics are applied on soil surfaces in manure, applied on days with large light intensity and water evaporation (Thiele-Bruhn and Peters, 2007). In particular quinolones and tetracyclines have been reported to be susceptible to photo-degradation (Torniainen, 1996; Davies, 1979). Sulfonamide photo-degradation was found to vary among different sulfonamides, the products showed to have no antibacterial activity (Zessel, 2014). On other potential abiotic degradation processes like reductive or oxidative transformation data for antibiotics are not available.

Biotic degradation or transformation of antibiotic residues will primarily be effectuated through the microbial populations native to the soil, but obviously the application of manure, with its high microbial content, may boost the microbial degradation of antibiotic residues. In many studies on antibiotic degradation in the environment, it was impossible to distinguish between the rate of biotic and abiotic degradation. However, an experiment comparing degradation of chloramphenicol in sterilized vs unsterilized soil convincingly showed the major role of the native microbial population in the degradation of this antibiotic residue (Berendsen, 2013). The extent, kinetics and process of degradation are mainly influenced by physicochemical properties of antibiotics such as structure, concentration, solubility, adsorption ability to soil, fixation ability to pores of soil matrix, and by environmental conditions, such as temperature, rainfall, and humidity (Tolls, 2001; Halling-Sørensen, 2002; Sarmah, 2006). As mentioned previously, sorption may affect bioavailability for microbial degradation (Jensen, 2001).

A number of studies have suggested that composting results in a significant decrease of extractable antibiotic concentrations in animal manures (Arikan, 2007; Dolliver, 2008, Selvam, 2012). Composting has been suggested as a practical and economical option for reducing antibiotic concentrations in manure before land application (Dolliver, 2008). For example, a study by Kim (2012) showed that composting reduced the concentration of extractable tetracyclines, sulfonamides and macrolides with $96 \%, 99 \%$ and $95 \%$, respectively. Anaerobic digestion has also been suggested as an effective method to degrade and remove antibiotics (Massé, 2014). The removal of antibiotics during such processes is mainly attributed to temperature dependent abiotic processes such as adsorption and degradation (Aust, 2008; Arikan, 2009). It is clear, however, that many of the factors determining the persistence of the antibiotic residues are closely interlinked. The individual processes and effects can impossibly be distinguished.

Additionally it should be taken into account that the analytical methods used may not always be capable of differentiating between degradation and absorption: i.e. if the extraction procedure is insufficient a decrease in drug residue concentration might be mistakenly interpreted for degradation. These considerations should be taken into account with respect to the overview given below on the persistence of individual and groups of antibiotics.

\subsection{Persistence of different types of antibiotics}

\subsubsection{Tetracyclines}

Tetracyclines are stable in acid media, but not in alkaline conditions, and form salts in both conditions (Doi, 2000; Halling-Sørensen, 2002). Their water solubility ranges between 230 and $5200\left(\mathrm{mg} \mathrm{L}^{-1}\right)$ with three pKa values of 3.3, 7.7, and 9.0, having amphoteric characteristics (Thiele-Bruhn, 2003). They are susceptible to photo-degradation (Doi, 2000) and form complexes with chelate divalent and trivalent metal ions such as $\mathrm{Mg}^{+2}, \mathrm{Ca}^{+2}, \mathrm{Fe}^{+2}, \mathrm{Zn}^{+2}$, and $\mathrm{Al}^{+2}, \mathrm{Fe}^{3+}, \mathrm{Al}^{3+}$, and $\beta$-diketones (Oka, 2000; 
Thiele-Bruhn, 2003). Chelating reduces bioavailability and thus reduces the antibacterial effect of tetracyclines. Complexation is therefore an important factor to determine the fate and effect of tetracyclines as divalent metals usually are present in high concentrations in the environment. Furthermore, tetracyclines are known to bind strongly to proteins and silanolic groups (Oka, 2000; Thiele-Bruhn, 2003).

There is minimal degradation of tetracycline in manure. A study on the degradation of tetracyclines (Bansal, 2012) showed that the process of degradation followed first order kinetics. The rate of degradation increased with increased moisture content, temperature, and amount of farm yield manure or nitrogen, and decreased with increasing antibiotic concentration. The detection rate of tetracyclines in manure ranged from 84.9 to $96.8 \%$ with a maximum concentration of residual chlortetracycline recovery reaching $764.4 \mathrm{mg} \mathrm{kg}^{-1}$ (Pan, 2011).

As a result of their physiochemical properties, tetracyclines are very stable and persistent. Oxytetracycline strongly absorbs to soil, $\mathrm{K}_{\mathrm{d}}$ values of oxytetacycline in sandy soil and sandy loam were found to be 417 and 1026 respectively (Rabølle and Spliid, 2000). Strong absorption correlates with limited leaching. A field study in which soil was fertilized with manure found $4.0 \mathrm{mg} \mathrm{kg}^{-1}$ tetracycline and $0.1 \mathrm{mg} \mathrm{kg}^{-1}$ chlortetracycline in the liquid manure, $86.2 \mathrm{mg} \mathrm{kg}^{-1}$ at the top layer (i.e. $0-10 \mathrm{~cm}$ depth) and $171.7 \mathrm{mg} \mathrm{kg}^{-1}$ at the deeper layer of the soil (i.e. 20-30 cm depth). Tetracyclines could not be detected at soil depths between 30 and $90 \mathrm{~cm}$, in soil or groundwater (Hamscher, 2002). In another study in which manure from feedlots was used, the concentration of chlortetracycline in manure was $401 \mu \mathrm{g} \mathrm{kg}^{-1}$, in soil $87 \mu \mathrm{g} \mathrm{kg}^{-1}$ at 0-30 $\mathrm{cm}$ depth and $55 \mathrm{\mu g} \mathrm{kg}^{-1}$ at $40 \mathrm{~cm}$ depth indicating a decrease in concentration with increasing soil depth (Aust, 2008). In addition, tetracyclines were detected in surface water at concentrations between 3 and $10 \mu \mathrm{g} \mathrm{L}^{-1}$ (Valverde, 2006).

Tetracyclines (particularly tetracycline and chlortetracycline) were found to be more persistent in soils than in manure (Bansal, 2012). Several studies showed that tetracyclines can adsorb strongly to clays (Allaire, 2006), soil (Bansal, 2012) and sediments (Rabølle and Spliid, 2000) indicating their persistence in different environments.

As a result of their extensive use and physiochemical properties, tetracyclines enter the environment in significant amounts and may build-up persistent residue concentrations in the soil. Thus, tetracyclines have the potential to pose a considerable risk of antibiotic resistance development in the environment. However it is important to note that very little is known on the effective bioavailability of the tetracyclines, considering the strong absorption potential of this residue group. It has been suggested that sorption limits microbial bioavailability, but experimental evidence for such a statement is not available yet.

\subsubsection{Macrolides}

Water solubility of macrolides varies between 0.15 and $45 \mathrm{mg} \mathrm{L}^{-1}$ with two $\mathrm{pK}_{\mathrm{a}}$ values of 7.7 and 8.9 (Thiele-Bruhn, 2003). Most of the published data concerning macrolides are on tylosin. Tylosin is unstable in acidic and alkaline media and relatively stable under neutral $\mathrm{pH}$ condition. As for most macrolide group antibiotics, the solubility of tylosin is high and increases with increased solvent polarity (Salvatore and Kats, 1993). The $\mathrm{K}_{\mathrm{d}}$ values for tylosin increase with decreasing $\mathrm{pH}$ due to the shift in tylosin speciation towards the positively charged species, increasing the ability to bind to negatively charged matrices such as soil and manure. (Wegst-Uhrich, 2014).

Based on $\mathrm{K}_{d}$ values, tylosin is more mobile than tetracyclines, but less than sulfonamides, olaquindox, and chloramphenicol (Kolz, 2005). The sorption behavior of tylosin in soil strongly depends on soil $\mathrm{pH}_{\text {, }}$ surface area, clay content, and cation-exchange capacity of the soil (Sassman, 2007). Percentage of clay, organic matter, cation exchange capacity, and manure amendment were positively correlated with sorption, and negatively correlated with mobility of tylosin in soil (Hu and Coats, 2009). In a laboratory sorption experiment, tylosin was found to have strong sorption behavior to different soil types with $\mathrm{K}_{\mathrm{d}}$ value that ranged 42 to $65 \mathrm{ml} \mathrm{g}^{-1}$ (Hu and Coats, 2009). Furthermore, these authors found that concentrations in leachate ranged from non-detectable to $0.27 \mathrm{ng} \mathrm{ml}^{-1}$ depending on soil properties and manure amendments. Also, in a study conducted by Rabølle and Spliid, no tylosin could 
be detected in the leachate of any of the soil types indicating its persistency and low mobility (Rabølle and Spliid, 2000).

The degradation of tylosin is affected by clay particles, organic matter in soil, and organic components in manure (Rabølle and Spliid; 2000; Kolz, 2005). Microbial degradation during storage of swine manure in lagoons has been reported to be $60-80 \%$ in $24 \mathrm{~h}$ under anaerobic conditions, whereas it was almost completely degraded in $12 \mathrm{~h}$ under aerobic condition (Kolz, 2005). On the other hand, the concentration of lincomycin and spectinomycin in manure kept in lagoons was found to be stable for up to 150d (Kuchta and Cessna, 2009).

As a result of its degradation and sorption behaviors, residual macrolides can be detected in manure slurries and afterwards can be transported in soil and water environments. In a survey of surface waters in the United States in 1999 and 2000, tylosin was listed as the most frequently detected antibiotic in surface waters (Kolpin, 2002). Tylosin was found in $13.5 \%$ of streams sampled with an average concentration of $0.04 \mu \mathrm{g} \mathrm{L}^{-1}$ and a maximum detected concentration of $0.28 \mu \mathrm{g} \mathrm{L}^{-1}$ (Kolpin, 2002). In another study, tylosin was described as one of the most likely water contaminants from agricultural runoffs (Huang, 2001). Tylosin can undergo biotic degradation in surface waters with an average lag time of 40 days and a half-life ranging from 24-54 days (Ingerslev, 2001).

In conclusion, considering the persistency and the actual occurrence of tylosin residues, and to a lesser extent other macrolides, may pose a risk with respect to antibiotic resistance development in the environment.

\subsubsection{Fluoroquinolones}

Most fluoroquinolones are amphoteric and they generally exhibit poor water solubility at pH 6-8 but are more soluble in acidic or basic media. Hence, they are insensitive to hydrolysis, resistant to microbial degradation and increased temperatures, but they can be degraded by UV light (Ternes, 2001; Thiele-Bruhn, 2003). Furthermore, fluoroquinolones are known to form stable complexes with several divalent and trivalent metal ions. Quinolones show very low biodegradability in standardized tests (Kümmerer, 2000) and were found to be very persistent in manure and soil matrixes (Gavalchin and Kats, 1994; Winckler and Grafe, 2001; Di Liguoro, 2004; Boxall, 2004; Boxall, 2012).

Fluoroquinolones have high sorption potential, with $\mathrm{Kd}$ values ranging from $496-61,000 \mathrm{I} \mathrm{kg}^{-1}$ for ciprofloxacin, enrofloxacin, and ofloxacin. (Picó and Andreu, 2007). Wastewater treatment was reported to yield a reduction of $88-92 \%$, mainly due to sorption on sewage sludge (Golet, 2003). As a result of their strong binding potential to the topsoil, fluoroquinolones constitute a limited threat with respect to surface water and groundwater contamination (Sukul and Spiteller, 2007; Golet, 2003). Multiple studies proved the persistency of fluoroquinolones in different matrixes. For example, concentrations as high as 1.37 to $6.68 \mathrm{mg} \mathrm{kg}^{-1}$ and $22.93 \mu \mathrm{g} \mathrm{kg}^{-1}$ of fluoroquinolones were detected respectively, in poultry litter and soil samples from Brazil (Leal, 2012). In another study in Turkey, only 42 and $24 \%$ of fluoroquinolones could be recovered in manure and spiked soil samples respectively (Karci and Balcioglu, 2009).

Thus, poor degradability and strong binding potential are the main mechanisms for fluoroquinolones dissipation in the environment, resulting in long persistency in soils and sediments. Potentially this poses a significant risk for antibiotic resistance development in the environment, but similar to what was mentioned earlier with respect to the tetracyclines, it is important to note that very little is known on the effective bioavailability of the residues in their soil-sorbed state.

\subsubsection{Beta-lactams}

$\beta$-lactams are rapidly hydrolyzed under mild acidic and basic conditions and are probably the class of antibiotics that is most susceptible to hydrolysis (Huang, 2001). Hydrolysis of $\beta$-lactams causes the opening of the $\beta$-lactam ring, yielding a product that is no longer antimicrobial. They show variable water solubility ranging between 22 and $10100 \mathrm{mg} \mathrm{L}^{-1}$ (Thiele-Bruhn, 2003). 
Generally, although there is limited information on their specific sorption properties, $\beta$-lactams are considered not very sensitive to adsorption (Thiele-Bruhn, 2003). Kim (2012) showed that amoxicillin was highly mobile in the two types of soils tested, and study on the fate of amoxicillin in domestic wastewater showed very little absorption (Githinji, 2011).

$\beta$-lactams can be degraded chemically or biologically within hours to days, depending on among others soil moisture. Microbial degradation is assumed to occur through $\beta$-lactamase enzymes, a wide spread resistance mechanism. Despite their relative poor stability, some studies did show the presence of $\beta$-lactam antibiotic residues in the environment. A study that analyzed a series of surface waters, soils, and liquid manures from North Rhine-Westphalia, Germany, found very low concentrations of $\beta$-lactams in all sample types, though on average less than $10 \mathrm{ng} \mathrm{L}^{-1}$ (Christian, 2003). Another study that analyzed water samples in order to evaluate the occurrence of $\beta$-lactams in a river and wastewater treatment plant, and found concentrations of $15-17 \mathrm{ng} \mathrm{L}^{-1}$ in influent samples and 9-11 $\mathrm{ng} \mathrm{L}^{-1}$ in surface water samples (Cha, 2006). $\beta$-lactams have been shown to remain biologically active once they enter the environment (Subbiah, 2011). However, considering their relative instability, they are less likely to persist substantially in the environment.

\subsubsection{Sulfonamides}

Sulfonamides are polar compounds with a solubility ranging from 0.1 to $8 \mathrm{~g} \mathrm{~L}^{-1}$ depending on the compound within the group (Sarmah, 2006). Sulfonamides function as weak acids in the physiological $\mathrm{pH}$ range (Thiele-Bruhn, 2003). They will occur in neutral form between $\mathrm{pH} 2.5-6$, and negatively charged in alkaline conditions. Sulfonamides are characterized by a low chelating ability, low binding constants, and high water solubility (Sukul and Spiteller, 2006). Sulfonamides have a low sorption coefficient and are considered to be the most mobile antibiotics (Tolls, 2001; Boxall, 2002).

Photo-degradation is considered an important degradation pathway (Batchu, 2014) and has been subject of many studies. With respect to biodegradation, Ingerslev and Halling-Sørensen, (2000) concluded that, according to the applied formal screening test, sulfonamides should not be classified as readily biodegradable. Sulfonamide adapted bacterial cultures however, were able to degrade sulfonamides very rapidly (0.2 to 3 days) (Ingerslev and Halling-Sørensen, 2000). The accelerating effect of previous exposure was also shown in a study in pig manure (Islas-Espinoza, 2012). It has been suggested that little or no biodegradation occurs whenever there are other easily biodegradable sources of carbon and nitrogen present (Drillia, 2005), which is obviously the case in manure and manure amended soils.

Sulfonamides obviously have the potential to enter soils, animal waste waters, sediments, groundwater, and surface waters (Lindsey, 2001; Kolpin, 2002; Thiele-Bruhn, 2003; Wei, 2011; Zhang, 2011), and have been observed in environmental samples. For example, a detectable concentration of sulfamethazine was found in agricultural soil 7 months after the application of manure (Christian, 2003). In another study, a concentration of up to $590 \mu \mathrm{g} \mathrm{L}^{-1}$ of sulfachloropyridazine was detected in drainage waters 7 days after manure application on clay loam soil (Boxall, 2002).

Based on their physiochemical properties and relative stability, sulfonamides are likely to occur in the environment in a bioavailable form and may therefor pose a risk with respect to antimicrobial resistance development.

\subsubsection{Aminoglycosides}

Aminoglycosides solubility is high, ranging from $10-500 \mathrm{~g} \mathrm{~L}^{-1}$. They are basic stronly polar polycationic compounds (Thiele-Bruhn, 2003). Information on their sorption potential is scarce. The amino groups of aminoglycosides can be positively charged by protonation under acidic conditions. The positive charge may facilitate adsorption to soil clay minerals that typically possess a negative charge (Huang, 2001). Very little information on their environmental occurrence is available. Despite their extensive use in livestock farming, no aminoglycosides were found in a broad study on the analysis of animal faeces (Berendsen, 2015). The lack of data prevents any conclusions on the role of aminoglycosides in the environment with respect to antimicrobial resistance. Nevertheless it has been suggested that environmental sources may contribute to the dissemination of high level aminoglycoside resistant bacteria (Rice, 1995). 


\section{Consequences of antibiotic residues in the environment}

\subsection{Effect on microbial communities}

Many antibiotics were originally identified as secondary metabolites produced by (soil) microorganisms and, therefore, represent a natural element in soil biology. Major exceptions to this are the sulfonamides and quinolones, which are fully synthetic chemicals. Several others, like most betalactams and some macrolides, are semisynthetic derivatives from naturally occurring compounds. Although the presence of (some) antibiotic residues could be considered a natural phenomenon, it has been clearly shown that the substantial amounts and concentrations originating from livestock production are disrupting natural soil ecosystems.

Environmental risk assessment for pharmaceuticals includes ecotoxicological testing on, among others, Daphnia and algae, but effects on microorganisms are mainly assessed based on carbon and nitrogen turnover in soil and respiration in activated sludge (Brandt, 2015). Effects of antibiotics on the structure of the microbial communities in natural environments are reviewed in detail by Ding and $\mathrm{He}$ (2010). The effect of antibiotic residues on the abundance and composition of the native microbial community depends on the type and amount of antibiotic residues, and the species of environmental microbes present (Zielezny, 2006, Hammesfahr, 2008). Studies investigating the effect of tylosin (Westergaard, 2001) and sulfadiazin (Hammesfahr, 2008) showed short term disturbance of the soil microbial community, as well as more permanent changes in the diversity of microbial community even after the concentration of the antibiotic had reduced to the minimum. Thiele-Bruhn (2005) investigated dose-related effects of sulfapyridine and oxytetracycline on microorganisms in different top soils, and found that effective doses inhibiting the microbial activity by $10 \%$, ranged from total antibiotic concentrations of $0.003-7.35 \mu \mathrm{g} \mathrm{g}^{-1}$. Furthermore, antibiotics significantly reduced numbers of soil bacteria, yielding dose related changes in the fungal to bacterial ratio. A study investigating the effect of antibiotic residues on aquatic photosynthetic organisms reported that tetracycline concentrations as low as $10 \mathrm{\mu g} \mathrm{L}^{-1}$ generated a significant effect on growth of Synechocystis and Lemna (Pomati, 2004).

The presence of antibiotic residues in the environment not only changes the structure and abundance of the soil microbial community, but also affects the ability of soil microorganisms to degrade contaminants, and their role in ecological functions such as methanogenesis, nitrogen transformation, and sulfate reduction in soil and aquatic environments (Keen and Patrick, 2013). The application of sulfadiazine amended manure to the soil has been reported to reduce some processes in nitrogen turnover in addition to reducing microbial activity (Kotzerke, 2008). In a study that investigated the effect of oxytetracycline on the nitrification process in a simple aquatic system found that nitrification was inhibited at the lowest level of oxytetracycline tested $\left(12.5 \mathrm{mg} \mathrm{L}^{-1}\right.$ ) (Klaver and Matthews, 1994). Biofilm stability and nitrification of a mixed nitrifying culture were shown to be affected at a concentration of $10 \mathrm{mg} \mathrm{L}^{-1}$ oxytetracycline, while chloramphenicol showed no effect (Campos, 2001). Inhibition of methanogenesis in an anaerobic digestion process was observed with sulfamethoxazole and ofloxacin (Fountoulakis, 2004).

A study investigating the ecotoxicity of erythromycin, oxytetracycline, sulfamethoxazole, ofloxacin, lincomycin and clarithromycin on aquatic organisms (bacteria, algae, rotifers, microcrustaceans and fish) showed limited acute ecotoxicity of antibiotics, with LC50 values varying between 10.23 to $1000 \mathrm{mg} \mathrm{L}^{-1}$ depending on the organism. However, chronic tests on the same organisms showed effects at much lower concentrations, in particular macrolide exposure to algae yielded inhibitory concentrations between 0.002 to $0.07 \mathrm{mg} \mathrm{L}^{-1}$ (Isidori, 2005). Other studies showed similar results, demonstrating very high sensitivity of algae to antibacterial agents (Christensen, 2006; Holten Lützhøft, 1999; Halling-Sørensen, 2000). 
Apart from their effects on soil microbial communities, the presence of antibiotic residues in the environment has also repeatedly been show to result in residues in crops (Kumar, 2005b; Boxall, 2006; Dolliver, 2008; Bassil, 2013; Chitescu, 2013; Berendsen, 2013).

\subsection{Effects on antimicrobial resistance}

Resistance genes are present naturally in the environment (D' Costa, 2011; Bhullar, 2012). Nevertheless, when long-term soil-series (from 1940 to 2008) from different locations in The Netherlands were analyzed, significant increases of the levels of all resistance genes were found (Knapp, 2010), showing an obvious anthropogenic contribution to the current situation. The effect on microbial resistance, however, is not part of the environmental risk assessment of antibiotic residues (Brandt, 2015).

Traditionally, it was assumed that selection of resistant bacteria occurs only at antibiotic concentrations above the Minimum Inhibitory Concentration (MIC) of the susceptible population. In general, reported concentrations of antibiotic residues in the environment are far below the regular bacterial MIC values. Thus, it has been generally assumed that microbial resistance is not favored at concentrations found in the environment (Kemper, 2008). However, evidence is steadily building up showing effects on antimicrobial resistance at concentrations much lower than the MIC. Several studies have described concentration-dependent biological responses of bacteria to antibiotics (Davies, 2006; Fajardo and Martínez, 2008; Aminov, 2009; Gullberg, 2011; Liu, 2011; Bernier and Surette, 2013; Andersson and Hughes, 2014). It has been suggested that bacteria might sense low, subinhibitory concentrations of antibiotics as extracellular chemicals, influencing gene expression and inducing various cellular responses affecting among others antibiotic susceptibility (Bernier and Surette, 2013).

Recent experiments demonstrated that selection of resistant bacteria can occur at antibiotic concentrations up to several hundred-folds below the MIC of the susceptible population (MIC susc) $_{\text {(Liu, }}$ 2011; Gullberg, 2011; Gullberg, 2014). Gullberg and co-authors performed competition experiments using susceptible and resistant bacterial strains of Escherichia coli and Salmonella enterica spp. They defined the minimal selective concentration (MSC) of an antibiotic as the lowest concentrations able to select for the resistant mutant strain. Their results showed that resistant mutants could be selectively enriched at very low antibiotic concentrations. The MSC values observed varied between $1 / 4$ to $1 / 230$ of the MIC value of the susceptible strain. The lowest absolute concentration showing selective effect was at $0.1 \mathrm{\mu g} \mathrm{L}^{-1}$ for ciprofloxacin. Also, de novo resistance was shown to occur at concentrations far below the MIC.

Evidence for selection of resistant bacteria at extremely low concentrations is also available under environmental conditions. Subbiah (2012) showed the strong potential of ceftiofur and its metabolites (CFM) on the persistence of resistant $E$. coli populations. Even though the residues were degraded in soil rapidly, exposure of urinary CFM $\left(\sim 13 \mu \mathrm{g} \mathrm{kg}^{-1}\right.$ final concentration) resulted in prolonged persistence of resistant bacteria in the soil ( $\sim$ two months). For sulfadiazine, concentrations of $150 \mu \mathrm{g}$ $\mathrm{kg}^{-1}$ in soil were shown to have a selective effect on the resistant population (Heuer, 2008). Increased selection for tetracycline resistant genes was also apparent at exposures as low as $20 \mu \mathrm{L} \mathrm{L}^{-1}$ OTC in surface water mesocosms (Knapp, 2008). Interestingly, a recent study suggests that the manure itself could be contributing to resistance, apparently by selectively supporting the growth of beta lactam resistant bacteria, although the exact mechanism is unknown (Udikovic-Kolica, 2014). Clearly, antibiotic concentrations found in manure and the environment ( $\$ 4.2)$ can select for resistant bacteria and thus contributes to the dissemination of resistance throughout the environment.

There is increasing concern about the very limited scope of the environmental risk assessment with respect to antibiotic residues (Boxall, 2012). Together with a growing number of studies showing that sub-inhibitory concentrations having an impact on bacterial communities and antimicrobial resistance, this has recently led to a call for improving the approach for assessing the effects of antibiotics

(Brandt, 2015). 


\section{Discussion}

Consequences of using antibiotics in animal production comprise an intricate system of interconnected processes: selection of resistant bacteria and the development of resistance reservoirs in farm animals, the transmission of antibiotic residues, resistant bacteria and resistant genes through products of animal origin to consumers, and the transfer of antibiotic residues, resistant genes or resistant microorganisms to the aquatic and terrestrial environment (Aarestrup, 1999; Levy, 2002; Boxall, 2003; Kümmerer, 2004; Kumar, 2005a; Acar and Moulin, 2006; Aminov, 2009; Chee-Sanford 2009). Figure 1 shows possible pathways related to the spread of antibiotic residues and resistant bacteria associated with livestock production.

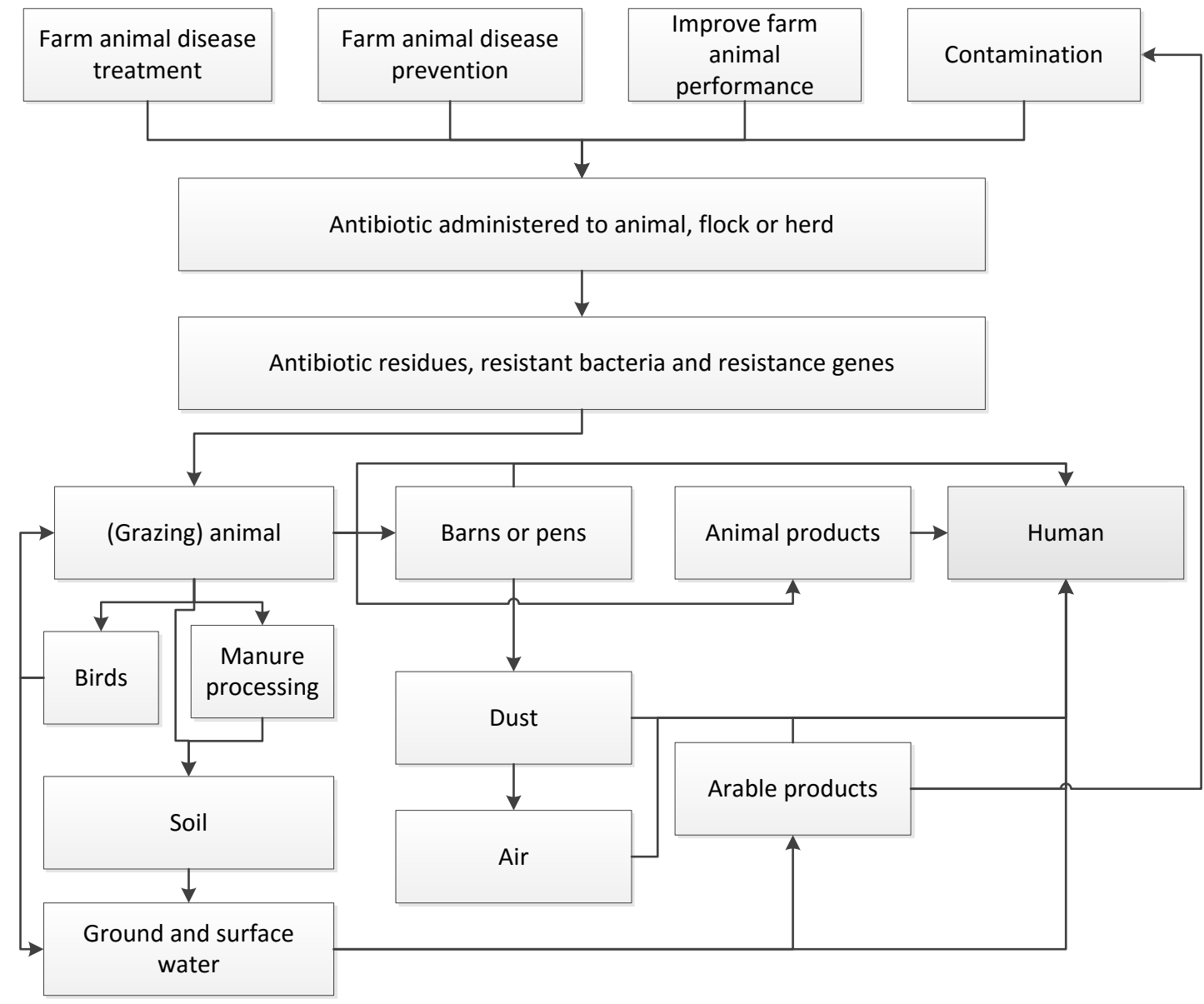

Figure 1 Possible paths of dissemination of antibiotics, antibiotic resistant bacteria and resistance genes through the environment related to animal production.

The use of manure for soil fertilization should be considered a main agricultural contributor to environmental contamination and transmission of antibiotic residues, resistant bacteria and resistance genes. Multiple studies have shown that animal manure fertilization increases the abundance of drugresistant bacteria and the frequency of antibiotic resistance genes in soils (Udikovic-Kolic, 2014; Marti, 2013; Gao, 2015; Garder, 2014). Underlying mechanisms are obviously more complex than just the simple addition of antibiotic resistant bacteria to farmland and depend on factors like bacterial fitness and transferability of genetic elements. The addition of copper and zinc to feed and the subsequent high concentrations in manure has been shown to co-select for antimicrobial resistance (Hölzel, 2012; Berg, 2005; Berg, 2010; Silveira, 2014). Different manure management techniques like composting 
and anaerobic digestion have been suggested to reduce prevalence of antibiotics as well as resistant bacteria and -genes in manure (Storteboom, 2007; Kim, 2012; Resende, 2014).

It remains difficult to assess the additional contribution of antibiotic residues to the further dissemination and persistence of antibiotic resistance in the environment. It has been shown, however, that antibiotics create a further opportunity for selection and persistence of antibiotic resistant bacteria in the environment, and that this might occur at much lower levels (sub-MIC) than previously assumed (Gullberg, 2011; Gullberg, 2014).

Limiting antibiotic consumption is the most obvious strategy for constraining the antibiotic resistance problems. Historical examples support the assumption that the frequency of antibiotic resistance declines when antibiotics are no longer applied. For instance, during the Finnish nationwide campaign to cut macrolide use for treatment of streptococcal infections (in human patients), macrolide resistance in S. pyogenes decreased by about $20 \%$ to less than $10 \%$ (Seppälä, 1997). Another wellknown example is the ban of the use of avoparcin as a growth promoter in Denmark. The government banned the use of avoparcin in 1995 which resulted in a decrease in the occurrence of glycopeptideresistant E. faecium in broilers; from $72.7 \%$ in 1995 to $5.8 \%$ in 2000 (Aarestrup, 2001). Also in the Netherlands the substantial decrease of antibiotic sales for animals (total sales between 2009, the index year as defined by the Ministry of Economic Affairs, and 2014, decreased by 58.1\%) is associated with a reduction of the general levels of antimicrobial resistance (MARAN, 2015). On the other hand, this direct causal association between usage of antibiotics and antimicrobial resistance is not always evident. Price (2007) observed no reduction of fluoroquinolone resistant Campylobacter in poultry after on-farm fluoroquinolone use had ceased. The fact that antibiotic resistance is likely to persists at a low level implies that reintroduction of antibiotics will quickly reselect resistant strains despite of months or years of nonuse (Levy and Marshall, 2004). Together with the phenomenon of co-selection, this seriously complicates efforts to eradicate antimicrobial resistance. Nevertheless, prudent and correct use of antibiotics is undisputable the primary policy for constraining the problem of antibiotic resistance. However, additional research is needed to be able to carry out sound risk assessment and to develop and implement effective measures to limit the dissemination of resistance:

1. As low concentrations of antibiotic residues might already select for resistant bacteria, to facilitate further research, development of sensitive and accurate techniques capable of measuring low concentrations of antibiotic residues in complex matrices (e.g. manure and environmental samples), should be developed.

2. It is advised to establish a "priority list" of most relevant antibiotics based on their use, exposure to the environment, behavior in manure and the environment and toxicity so research can be focused on the most relevant compounds.

3. Determination of threshold concentrations for selection and propagation of antimicrobial resistance in vitro, in vivo and in situ for all relevant antibiotics (both used in animal and human medicine) is essential.

4. As the environment is exposed to veterinary antibiotics, primarily through manure, the fate of all relevant antibiotics during manure storage, processing and transport should be determined, including the selection of resistant bacteria under the applied conditions. Manure processing could be an important phase for development of intervening measures.

5. Also, the fate of all relevant antibiotics in soil (after manure application) should be studied. To understand in what reservoirs selection of resistance can occur due to the presence of antibiotic residues in the environment, knowledge on the metabolism, stability, bioavailability, etc. of antibiotics in the environment is mandatory. For this, mesocosm studies are suggested to determine the fate of antibiotics under natural, yet controlled conditions.

6. Research is needed on the role of heavy metals and biocides on co-selection in the presence of antibiotic residues in the gut, manure and the environment. Therefore, also the fate of these compounds in the different reservoirs should be studied as well as their influence on the dissemination of resistance. 


\section{Conclusions}

The emergence and spread of the resistant bacteria and genes as a result of veterinary antibiotic treatment is a well-recognized issue and its relevance is generally acknowledged. Treatment of animals, however, also results in the release of antibiotic residues into the environment. The persistence of antibiotics in manure and soil depends on factors like soil type (e.g. organic content) and physical-chemical characteristics of the particular antibiotic. Very little is known about antibiotic concentrations that generate selective pressure and promote the persistence and spread of antibiotic resistance in the environment. However, selective environments may occur at concentrations far below the MIC, which was traditionally considered as the minimum concentration provoking antibiotic resistance. Substantial concentrations of antibiotic residues occur in soil and water, in particular at locations close to intensive farming. Based on the comparison of results reported in individual studies, it is expected that antibiotic residue concentrations in the environment contribute to persistence and promote further spreading of antibiotic resistance.

To enable risk assessment and development of management programs, research on defining the minimal threshold concentrations that induce or support propagation of antibiotic resistance is of great importance. Furthermore, determination of the bioavailability of antibiotics in situ to classify antibiotics according to their risk characterization profile is critical. The development of sensitive and accurate analytical techniques that are able to measure these antibiotic residue concentrations in all relevant matrices, is also mandatory. Therefore, a comprehensive study is urgently needed to examine the fate of antibiotic residues and their effect on resistance in all relevant reservoirs (manure, soil, water and plants). Research necessary to understand the effect of antibiotic residues on resistance in the gut, manure and the environment is specified in chapter 6 . 


\section{$7 \quad$ Acknowlegement}

The authors would like to thank the Dutch Ministry of Economic Affairs for funding the project within project WOT-02-003-065. We thank Henk Aarts (RIVM) for his kind contribution and input. 


\section{References}

Aarestrup, F.M. 1999. Association between the consumption of antimicrobial agents in animal husbandry and the occurrence of resistant bacteria among food animals. J. Antimicrob. Agents, 12:279-285

Aarestrup, F.M., A.M. Seyfarth, H.D. Emborg, K. Pedersen, R.S. Hendriksen, and F. Bager. 2001. Effect of abolishment of the use of antimicrobial agents for growth promotion on occurrence of antimicrobial resistance in fecal enterococci from food animals in Denmark. Antimicrob. Agents Chemother., 45(7): 2054-9.

Aarestrup, F.M., H.C. Wegener, and P. Collignon. 2008. Resistance in bacteria of the food chain: Epidemiology and control strategies. Expert Reviews, 6(5): 733-750.

Acar, J.F., and G. Moulin. 2006. Antimicrobial resistance at farm level. Rev. Sci. tech. Off. Int. Epiz, 25 (2): 775-792.

Alekshun, M.N., and S.B. Levy. 2007. Molecular mechanisms of antibacterial multidrug resistance. Cell, 128(6): 1037-1050.

Allaire, S.E., J. Del Castillo, and V. Juneau. 2006. Sorption kinetics of chlortetracycline and tylosin on sandy loam and heavy clay soils. J. Environ. Qual., 35:969-972.

Aminov, R.I. 2009. The role of antibiotics and antibiotic resistance in nature. Environ. Microbiol., 11(12): 2970-2988.

Aminov, R.I. 2011. Horizontal Gene Exchange in Environmental Microbiota. Front. Microbiol. 2: 158.

Andersson, D.I., and D. Hughes. 2014. Microbiological effects of sub-lethal levels of antibiotics. Nature Rev. Microb., 12 : 465-478.

Andremont, A. 2003. Commensal flora may play key role in spreading antibiotic resistance. ASM News, 69:601-607.

Arikan, O.A., L.J. Sikora, W. Mulbry, S.U. Khan, and G.D. Foster. 2007. Composting rapidly reduces levels of extractable oxytetracycline in manure from therapeutically treated beef calves. Bioresource Technol., 98(1):169-176.

Arikan, O.A., W. Mulbry, and C. Rice. 2009. Management of antibiotic residues from agricultural sources: use of composting to reduce chlortetracycline residues in beef manure from treated animals. J. Hazardous Materials, 164:483-489.

Aust, M.O., F. Godlinski, G.R. Travis, X. Hao, T.A. McAllister, and P. Leinweber. 2008. Distribution of sulfamethazine, chlortetracycline and tylosin in manure and soil of Canadian feedlots after subtherapeutic use in cattle. Environ. Pollut., 156:1243-1251.

Bager, F., M. Madsen, J. Christensen, and F.M. Aarestrup. 1997. Avoparcin used as a growth promoter is associated with the occurrence of vancomycin-resistant Enterococcus faecium on Danish poultry and pig farms. Prev. Vet. Med., 31:95-112.

Bansal, O.P. 2012. A laboratory study on degradation of tetracycline and chlortetracycline in soils of aligarh district as influenced by temperature, water content, concentration of farm yield manure, nitrogen and tetracyclines. Proc. Nat. Acad. Sci. India, Section B: Bio. Sc., 82(4): 503-509.

Barbosa, T.M., and S.B. Levy. 2000. The impact of antibiotic use on resistance development and persistence. Drug Resist. Update., 3: 303-311.

Bassil, R.J., I.I. Bashour, F.T. Sleiman, and Y.A. Abou-Jawdeh. 2013. Antibiotic uptake by plants from manure-amened soils. J. Environ. Sci. and Health, part B, 48:570-574.

Batchu, S.R., R. Venkata, Panditi, Piero R. Gardinali. 2014. Photodegradation of sulfonamide antibiotics in simulated and natural sunlight: Implications for their environmental fate, J. Environm. Sci. Health, 49:3, 200-211.

Berg, J., A. Tom-Petersen, and O. Nybroe. 2005. Copper amendment of agricultural soil selects for bacterial antibiotic resistance in the field. Lett. Appl. Microbiol., 40:146-151.

Berg, J., M.K. Thorsen, P.E. Holm, J. Jensen, O. Nybroe, and K.K. Brandt. 2010. Cu exposure under field conditions co-selects for antibiotic resistance as determined by a novel cultivationindependent bacterial community tolerance assay Environ. Sci. Technol., 44:8724-8728. 
Berendsen, B.J.A., M.G. Pikkemaat, P.F.A.M. Romkens, R. Wegh, M. van Sisseren, A.A.M. Stolker, and W.M.F. Nielen. 2013. Occurrence of chloramphenicol in crops through natural production by bacteria in soil. J. Agric. Food Chem., 61: 4004 - 4010.

Berendsen, B.J.A., R.S. Wegh, J. Memelink, T. Zuidema, and A.A.M. Stolker. 2015. The analysis of animal faeces as a tool to monitor antibiotic usage. Talanta, 132: 258 - 268.

Bernier, S.P., and M.G. Surette. 2013. Concentration-dependent activity of antibiotics in natural environments. Front. Microbiol., 4(20):1-14.

Bhullar, K., N. Waglechner, A. Pawlowski, K. Koteva, E.D. Banks, M.D. Johnston, H.A. Barton, and G.D. Wright. 2012. Antibiotic resistance is prevalent in an isolated cave microbiome. PLoS ONE, 7(4): e34953.

Boxall, A.B.A. 2011. Fate and transport of antibiotics in soil systems. Antimicrobial Resistance in the Environment, First Edition. Edited by Patricia L. Keen and Mark H.M.M. Montforts. John Wiley \& Sons, Inc.

Boxall, A.B.A., D.W. Kolpin, B. Halling-Sørensen, and J. Tolls. 2003. Are veterinary medicines causing environmental risks? Environ. Sci. Technol., 37: 286A-294A.

Boxall, A.B.A., L.A. Fogg, P. Blackwell, P. Kay, E.J. Pemberton, and A. Croxford. 2004. Veterinary medicines in the environment. Rev. Environ. Contam. Toxicol., 182:1-91.

Boxall, A.B.A., P. Blackwell, R. Cavallo, P. Kay, and J. Tolls. 2002. The sorption and transport of a sulphonamide antibiotic in soil systems. Toxicol. Lett., 131:19-28.

Boxall, A.B.A., P. Johnson, E.J. Smith, C.J. Sinclair, E. Stutt, and L.S. Levy. 2006. Uptake of veterinary medicines from soils into plants. J. Agric. Food Chem., 54:2288-2297.

Boxall, A.B., M.A. Rudd, B.W. Brooks, D.J. Caldwell, K. Choi et al. 2012. Pharmaceuticals and personal care products in the environment: what are the big questions? Environ. Health Perspect., 120(9):1221-9.

Brady, M.S., N.S. White, and S.E. Katz. 1993. Resistance development potential of antibiotic/antimicrobial residue levels designated as "Safe Levels". J. Food Prot., 56(3): 229-233.

Brandt, K.K., A. Amézquita, T. Backhaus, A. Boxall, A. Coors, T. Heberer, J.R. Lawrence, J. Lazorchak, J. Schönfeld, J.R. Snape, Y.G. Zhu, and E. Topp. 2015. Ecotoxicological assessment of antibiotics: A call for improved consideration of microorganisms. Environ. Int., 85:189-205.

Cabello, F.C. 2004. Antibiotics and aquaculture in Chile: implications for human and animal health. Rev. Med. Chile, 132: 1001-1006.

Campos, J.L., J.M. Garrido, R. Méndez, and J.M. Lema. 2001. Effect of two broad-spectrum antibiotics on activity and stability of continuous nitrifying system. App. Biochem. Biotechnol., 95:1-10.

Catry, B., H. Laevens, L.A. Devriese, G. Opsomer, and A. de Kruif. 2003. Antimicrobial resistance in livestock. J. Vet. Pharmacol. Ther., 26: 81-93.

Cha, J.M., S. Yang, and K.H. Carlson. 2006. Trace determination of beta-lactam antibiotics in surface water and urban wastewater using liquid chromatography combined with electrospray tandem mass spectrometry. J. Chromatogr., 1115:46-57.

Chee-Sanford, J.C., R.I. Mackie, S. Koike, I.G. Krapac, Y.F. Lin, A.C. Yannarell, S. Maxwell, and R.I. Aminov. 2009. Fate and transport of antibiotic residues and antibiotic resistance genes following land application of manure waste. J. Environ. Qual., 38(3):1086-108.

Chitescu, C.L., A.I. Nicolau, and A.A.M. Stolker. 2013. Uptake of oxytetracycline, sulfamethoxazole and ketoconazole from fertilised soils by plants. Food Addit. Contam., Part A, 30 (6):1138-1146.

Christian, T., R.J. Schneider, H.A. Färber, D. Skutlarek, M.T. Meyer, and H.E. Goldbach. 2003. Determination of antibiotic residues in manure, soil, and surface waters. Acta Hydrochim. Hydrobiol., 31 (1):36-44.

Cohen Stuart, J., T. van den Munckhof, G. Voets, J. Scharringa, A. Fluit, and M.L. Hall. 2012. Comparison of ESBL contamination in organic and conventional retail chicken meat. Int. J. Food Microbiol., 154(3):212-4.

Christensen, A.M., F. Ingerslev, and A. Baun. 2006. Ecotoxicity of mixtures of antibiotics used in aquacultures. Environ. Toxicol. Chem., 25(8):2208-15.

Davies, A.K., J.F. McKellar, G.O. Phillips, and A.G. Reid. 1979. Photochemical oxidation of tetracycline in aqueous solution. J. Chem. Soc. Perk. T 2, 369-375.

Davies, J., and D. Davies. 2010. Origins and evolution of antibiotic resistance Microbiol. Mol. Biol. Rev., 74:417-433.

Davies, J., G.B. Spiegelman, and G. Yim. 2006. The world of subinhibitory antibiotic concentrations. Curr. Opin. Microbiol., 9: 445-453. 
D'Costa, V.M., C.E. King, L.K.M. Morar, W.W.L. Sung, C. Schwarz, D. Froese, G. Zazula, F. Calmels, R. Debruyne, G.B. Golding, H.N. Poinar, and G.D. Wright. 2011. Antibiotic resistance is ancient. Nature, 477: 457-461.

Dohmen, W., M.J. Bonten, M.E. Bos, S. van Marm, J. Scharringa, J.A. Wagenaar, and D.J. Heederik. 2015. Carriage of extended-spectrum $\beta$-lactamases in pig farmers is associated with occurrence in pigs. Clin. Microbiol. Infect., 21(10):917-23.

Doi, A.M., and M.K. Stoskopf. 2000. The kinetics of oxytetracycline degradation in deionized water under varying temperature, $\mathrm{pH}$, light, substrate, and organic matter. J. Aquat. Anim. Health, $12: 246-253$.

Dolliver, H., S. Gupta, and S. Noll. 2008. Antibiotic degradation during manure composting. J. Environ. Qual., 37(3):1245-1253.

Drillia, P., S.N. Dokianakis, M.S. Fountoulakis, M. Kornaros, K. Stamatelatou, and G. Lyberatos. 2005. On the occasional biodegradation of pharmaceuticals in the activated sludge process: The example of the antibiotic sulfamethoxazole. J. Hazard. Mater., 122: 259-265.

Dunlop, R.H., S.A. McEwen, A.H. Meek, R.C. Clarke, W.D. Black, and R.M. Friendship. 1998. Associations among antimicrobial drug treatments and antimicrobial resistance of fecal Escherichia coli of swine of 34 farrow to finish farms in Ontario, Canada. Prev. Vet. Med., 34:283-305.

EC, 1996. COUNCIL DIRECTIVE 96/23/EC of 29 April 1996 on measures to monitor certain substances and residues thereof in live animals and animal products and repealing Directives 85/358/EEC and 86/469/EEC and Decisions 89/187/EEC and 91/664/EEC. Official J. of the EU L 125/10.

EC, 2001. DIRECTIVE 2001/82/EC of the European Parliament and of the Council of 6 November 2001 on the Community code relating to veterinary medicinal products. Official J. of the EU L $311 / 1$.

EC, 2003. REGULATION (EC) No 1831/2003 of the European Parliament and of the Council of 22 September 2003 on additives for use in animal nutrition. Official J. of the EU L 268/29.

EC, 2009. REGULATION (EC) No. 470/2009 of the European Parliament and of the Council 6 May 2009 laying down Community procedures for the establishment of residue limits of pharmacologically active substances in foodstuffs of animal origin, repealing Council Regulation (EEC) No. 2377/90 and amending Directive 2001/82/EC of the European Parliament and of the Council and Regulation (EC) No. 726/2004 of the European Parliament and of the Council. Official J. of the EU L 152/11.

EC, 2010. COMMISSION REGULATION (EU) No 37/2010 of 22 December 2009 on pharmacologically active substances and their classification regarding maximum residue limits in foodstuffs of animal origin. Official J. of the EU L $15 / 1$.

EC, 2015. Commission staff working document Progress report on the Action plan against the rising threats from Antimicrobial Resistance. SANTE/10251/2015.

EFSA, 2008. Foodborne antimicrobial resistance as a biological hazard, Scientific Opinion of the Panel on Biological Hazards.

EFSA, 2015. EU Summary Report on antimicrobial resistance in zoonotic and indicator bacteria from humans, animals and food in 2013. EFSA Journal 2015, 13(2):4036.

EMA, 2008. Maximum residue limit assessment reports, Penicillins: Summary report - Committee for Veterinary Medicinal Products. Retrieved from http://www.ema.europa.eu/ema/.

Endtz, H.P., G.J. Ruijs, B. van Klingeren, W.H. Jansen, T. van der Reyden, and R.P. Mouton. 1991. Quinolone resistance in campylobacter isolated from man and poultry following the introduction of fluoroquinolones in veterinary medicine. J. Antimicrob. Chemother., 27, 199-208.

EZ, 2015. Ministerie van Economische Zaken, Nationaal Strategisch Plan Aquacultuur 2014-2020. Retrieved from https://www.rijksoverheid.nl/documenten/kamerstukken/ 2015/03/18/nationaalstrategisch-plan-aquacultuur-nspa

FAO, 2014. The state of world fisheries and aquaculture. Retrieved from http://www.fao.org/fishery/publications/sofia/en.

Fajardo, A., and J.L. Martínez. 2008. Antibiotics as signals that trigger specific bacterial responses. Curr. Opin. Microbiol., 11: 161-167.

Fernández, L., and R.E. Hancock. 2012. Adaptive and mutational resistance: role of porins and efflux pumps in drug resistance. Clin. Microbiol. Rev., 25(4):661-81.

Figueroa-Diva, R.A., D. Vasudevan, and A.A. MacKay. 2010. Trends in soil sorption coefficients within common antimicrobial families. Chemosphere, 79(8):786-93.

Food Safety Authority or Ireland, 2015, Report of the Scientific Committee of the Food Safety Authority of Ireland. Potential for Transmission of Antimicrobial Resistance in the Food Chain. ISBN 978-1-910348-01-7. 
Fountoulakis, M., P. Drillia, K. Stamatelatou, and G. Lyberatos. 2004. Toxic effect of pharmaceuticals on methanogenesis. Water Sci. Technol., 250(5):335-40.

Gao, L., J. Hu, X. Zhang, L. Wei, S. Li, Z. Miao, and T. Chai. 2015. Application of swine manure on agricultural fields contributes to extended-spectrum $\beta$-lactamase-producing Escherichia coli spread in Tai'an, China. Front. Microbiol., 6:313.

Garder, J.L., T.B. Moorman, and M.L. Soupir. 2014.Transport and persistence of tylosin-resistant enterococci, genes, and tylosin in soil and drainage water from fields receiving Swine manure. J. Environ. Qual., 43(4):1484-93.

Gavalchin, J. and S.E. Katz. 1994. The persistence of fecal-borne antibiotics. J. AOAC Int., 77(2): 481-485.

Githinji, L.J.M., M.K. Musey, and R.O. Ankumah. 2011. Evaluation of the fate of ciprofloxacin and amoxicillin in domestic wastewater. Water Air Soil Pollut., 219:191-201.

Golet, E.M., I. Xifra, H. Siegrist, A.C. Alder, and W. Giger. 2003. Environmental exposure assessment of fluoroquinolone antibacterial agents from sewage to soil. Environ. Sci. Technol., 37:3243-3249.

Grave, K., J.A.J. Torren-Edo, and D. Mackay. 2010. Comparison of the sales of veterinary antimicrobial agents between 10 European countries. J. Antimicrob. Chemother., 65:2037-2040.

Guillemot, D., C. Carbon, B. Balkau, P. Geslin, H. Lecoeur, F. Vauzelle-Kervroëdan, G. Bouvenot, and E. Eschwége. 1998. Low dosage and long treatment duration of b-lactam: risk factors for carriage of penicillin-resistant Streptococcus pneumoniae. JAMA., 279(5):365-70.

Gullberg, E., S. Cao, O.G. Berg, C. Ilbäck, L. Sandegren, D. Hughes, and D.I. Andersson. 2011. Selection of resistant bacteria at very low antibiotic concentrations. PLoS Pathog. 7(7): e1002158.

Gullberg, E., L.M. Albrecht, C. Karlsson, L. Sandegren, and D.I. Andersson. 2014. Selection of a multidrug resistance plasmid by sublethal levels of antibiotics and heavy metals. mBio 5(5): 1918-14.

Halling-Sørensen, B. 2000. Algal toxicity of antibacterial agents used in intensive farming. Chemosphere; 40:731-9.

Halling-Sørensen, B., G. Sengeløv, and J. Tjørnelund. 2002. Toxicity of tetracyclines and tetracycline degradation products to environmentally relevant bacteria, including selected tetracycline-resistant bacteria. Arch. Environ. Contam. Toxicol., 42: 263-271.

Hammesfahr, U., H. Heuer, B. Manzke, K. Smalla, and S. Thiele-Bruhn. 2008. Impact of the antibiotic sulfadiazine and pig manure on the microbial community structure in agricultural soils. Soil Biol. Biochem., 40(7):1583-1591.

Hamscher, G., S. Sczesny, H. Höper, H. Nau. 2002. Determination of persistent of tetracycline residues in solid fertilized with liquid manure by high-performance chromatography with electrospray ionization tandem mass spectrometry. Anal. Chem., 74:1509-1518.

Heuer, H., A. Focks, M. Lamshöft, K. Smalla, M. Matthies, and M. Spiteller. 2008. Fate of sulfadiazine administered to pigs and its quantitative effect on the dynamics of bacterial resistant genes in manure and manured soil. Soil Biol. Biochem., 40:1892-1900.

Hoek, van A.H., C. Veenman, W.M. van Overbeek, G. Lynch, A.M. de Roda Husman, and H. Blaak. 2015. Prevalence and characterization of ESBL- and AmpC-producing Enterobacteriaceae on retail vegetables. Int. J. Food Microbiol., 204:1-8.

Holten Lützhøft, H.C., B. Halling-Sørensen, and S.E. Jørgensen. 1999. Algal toxicity of antibacterial agents applied in Danish fish farming. Arch. Environ. Contam. Toxicol., 36:1- 6.

Hölzel, C.S., C. Müller, K.S. Harms, S. Mikolajewski, S. Schäfer, K. Schwaiger, and J. Bauer. 2012. Heavy metals in liquid pig manure in light of bacterial antimicrobial resistance. Environ. Res., 113:21-27.

Hou, J.P., and J.W. Poole. 1969. Kinetics and mechanism of degradation of ampicillin in solution. J. Pharm. Sci., 58: 447-454.

Hu, D., and J.R. Coats. 2009. Laboratory evaluation of mobility and sorption for the veterinary antibiotic, tylosin, in agricultural soils. J. Environ. Monit., 11:1634-1638.

Huang, C.-H., J.E. Renew, K.L. Smeby, K. Pinkston, and D.L. Sedlak. 2001. Assessment of potential antibiotic contaminants in water and preliminary occurrence analysis. J. Contemp. Water Res. Educ., 120:30-40.

Ingerslev, F., and B. Halling-Sørensen. 2000. Biodegradability properties of sulfonamides in activated sludge. Environ. Toxicol. Chem., 19: 2467-2473. 
Ingerslev, F., L. Toräng, M.L Loke, B. Halling-Sørenson, and N. Nyholm. 2001. Primary biodegradation of veterinary antibiotics in aerobic and anaerobic surface water simulation systems. Chemosphere, 44: 865-872.

Isidori, M., M. Lavorgna, A. Nardelli, L. Pascarella, and A. Parrella. 2005. Toxic and genotoxic evaluation of six antibiotics on non-target organisms. Sci. Total. Environ., 346: 87- 98.

Islas-Espinoza, M., B.J. Reid, M. Wexler, and P.L. Bond. 2012. Soil bacterial consortia and previous exposure enhance the biodegradation of sulfonamides from pig manure. Microb. Ecol., 64(1): 140-51.

Ivanov, I.I., and K. Honda. 2012. Intestinal commensal microbes as immune modulators. Cell Host Microbe, 12(4): 496-508.

Jacobs-Reitsma, W.F., P.M. Koenraad, N.M. Bolder, and R.W. Mulder. 1994. In vitro susceptibility of Campylobacter and Salmonella isolates from broilers to quinolones, ampicillin, tetracycline, and erythromycin. Vet. Q.;16(4):206-8.

Jensen, J., C.G. Daughton, and T. Jones-Lepp. 2001. Veterinary Medicines and Soil Quality: The Danish Situation as an example. ACS Symposium Series. 791:282-302.

Johnson, J.R., M.A. Kuskowski, K. Smith, T.T. O’Bryan, and S. Tatini. 2005. Antimicrobial-resistant and extraintestinal pathogenic Escherichia coli in retail foods. J. Infect. Dis., 191:1040-1049.

Karci, A., and I.A. Balcioglu. 2009. Investigation of the tetracycline, sulfonamide, and fluoroquinolone antimicrobial compounds in animal manure and agricultural soils in Turkey. Sci. Total Environ., 407(16):4652-64.

Keen, P.L., and D.M. Patrick. 2013. Tracking change: A look at the ecological footprint of antibiotics and antimicrobial resistance. Antibiotics, 2:191-205.

Kemper, N. 2008. Veterinary antibiotics in the aquatic and terrestrial environment. Ecol. Indicators, $8: 1-13$.

Kim, K.R., G. Owens, Y.S. Ok, W.K. Park, D.B. Lee, and S.I. Kwon. 2012. Decline in extractable antibiotics in manure-based composts during composting. Waste Manag., 32(1):110-6.

Kim, Y.K., S.J. Lima, M.H. Han, and J.Y. Cho. 2012. Sorption characteristics of oxytetracycline, amoxicillin, and sulfathiazole in two different soil types. Geoderma, 185-186: 97-101.

Klare, I., H. Heier, H. Claus, R. Reissbrodt, and W. van Witte. 1995. A-mediated high-level glycopeptide resistance in Enterococcus faecium from animal husbandry. FEMS Microbiol. Lett., 125, 165-71.

Klaver, A.L., and R.A. Matthews. 1994. Effects of oxytetracycline on nitrification in a model aquatic system. Aquaculture, 123: 237-247.

Knapp, C.W., C.A. Engemann, M.L. Hanson, P.L. Keen, K.J. Hall, and D.W. Graham. 2008. Indirect evidence of transposon-mediated selection of antibiotic resistant genes in aquatic systems at lowlevel oxytetracycline exposures. Environ. Sci. Technol., 42:5348-5353.

Knapp, C.W., J. Dolfing, P.A. Ehlert, and D.W. Graham. 2010. Evidence of increasing antibiotic resistant gene abundances in archived soils since 1940. Environ. Sci. Technol. 44:580-587.

Kolpin, D.W., E.T. Furlong, M.T. Meyer, E.M. Thurman, S.D. Zaugg, L.B. Barber, and H.T. Buxton. 2002. Pharmaceuticals, hormones, and other organic wastewater contaminants in U. S. streams, 1999-2000: a national reconnaissance. Environ. Sci. Technol., 36:1202-1211.

Kotzerke, A., S. Sharma, K. Schauss, H. Heuer, S. Thiele-Bruhn, K. Smalla, B.M. Wilke, and M. Schloter. 2008. Alterations in soil microbial activity and $\mathrm{N}$-transformation processes due to sulfadiazine loads in pig-manure. Environ. Poll., 153: 315-322.

Kruse, H., B.K. Johansen, L.M. Rorvik, and G. Schaller. 1999. The use of avoparcin as a growth promoter and the occurrence of vancomycin-resistant Enterococcus species in Norwegian poultry and swine production. Microb. Drug Resist., 5:135-139.

Kuchta, S.L., and A.J. Cessna. 2009. Lincomycin and spectinomycin concentrations in liquid swine manure and their persistency during simulated manure storage. Arch. Environ. Contam. Toxicol., 57:1-10.

Kumar, K., S.C. Gupta, Y. Chander, and A. Singh. 2005a. Antibiotic use in agriculture and its impact on the terrestrial environment. Adv. Agron., 87:1-54.

Kumar, K., S.C. Gupta, S.K. Baidoo, Y. Chander, and C.J. Rosen. 2005b. Antibiotic uptake by plants from soil fertilized with animal manure. J. Environ. Qual., 34:2082-2085.

Kümmerer, K., A. al-Ahmad, and V. Mersch-Sundermann. 2000. Biodegradability of some antibiotics, elimination of the genotoxicity and affection of wastewater bacteria in a simple test.

Chemosphere, 40(7):701-10. 
Kümmerer, K. 2004. Resistance in the environment. J. Antimicrob. Chemother., 54:311-320.

Leal, R.M.P., R.F. Figueira, V.L. Tornisielo, and J.B. Regitano. 2012. Occurrence and sorption of fluoroquinolones in poultry litters and soils from Sao Paulo State, Brazil. Sci. Total Environ., 432:344-9.

Levy, S.B. 2001. Antibiotic resistance: consequences of inaction. Clin. Infect. Dis.(3):S124-9.

Levy, S.B. 2002. The antibiotic paradox. How the misuse of antibiotics destroys their curative powers, Book review $2^{\text {nd }}$ edn Int Microbiol, 5: 155-156.

Levy, S.B., and B. Marshall. 2004. Antibacterial resistance worldwide: causes, challenges and responses. Nature Medicine supp., 10(12): S122-129.

Lindsey, M.E., M. Meyer, and E.M. Thurman. 2001. Analysis of trace levels of sulfonamide and tetracycline antimicrobials in groundwater and surface water using solid-phase extraction and liquid chromatography/mass spectrometry. Anal. Chem., 73:4640-4646.

Liu, A., A. Fong, E. Becket, J. Yuan, C. Tamae, L. Medrano, M. Maiz, C. Wahba, C. Lee, K. Lee, K.P. Tran, H. Yang, R.M. Hoffman, A. Salih, and J.H. Miller. 2011. Selective advantage of resistant strains at trace levels of antibiotics: a simple and ultrasensitive color test for detection of antibiotics and genotoxic agents. Antimicrob. Agents Chemother. 55, 1204-1210.

MARAN, 2015. Monitoring of Antimicrobial Resistance and Antibiotic Usage in Animals in the Netherlands in 2014. Retrieved from http://www.wageningenur.nl/nl/ExpertisesDienstverlening/Onderzoeksinstituten/ Central-Veterinary-Institute/Publicaties-CVI/MARANRapporten.

Marti, R., A. Scott, Y.C. Tien, R. Murray, L. Sabourin, Y. Zhang, and E. Topp. 2013. Impact of manure fertilization on the abundance of antibiotic-resistant bacteria and frequency of detection of antibiotic resistance genes in soil and on vegetables at harvest. Appl. Environ. Microbiol., 79(18):5701-9.

Martinez-Carballo, E., C. Gonzalez-Barreiro, S. Scharf, and O. Gans. 2007. Environmental monitoring study of selected veterinary antibiotics in animal manure and soils in Austria. Environ. Pollut., 148:570-9.

Massé, D.I., N.M.C. Saady, and Y. Gilbert. 2014. Potential of biological processes to eliminateantibiotics in livestock manure: an overview. Animals, 4:146-163.

McEwen, S.A., and P.J. Fedorka-Cray. 2002. Antimicrobial use and resistance in animals. Clin. Infect. Dis., 34(3):S93-106.

McDermott, P.F., R.D. Walker, and D.G. White. 2003. Antimicrobials: modes of action and mechanisms of resistance. Int. J. Toxicol., 22(2):135-43.

Nouws, J. 1992. Pharmacokinetics in immature animals: A review. Anim. Sci. 70:3627-3634

O'Brien, T.F. 2002. Emergence, spread, and environmental effect of antimicrobial resistance: how use of an antimicrobial anywhere can increase resistance to any antimicrobial anywhere else. Clin. Infect. Dis., 34:S78-S84.

OECD, 2000. OECD Guideline for testing of chemicals; Test No 106: Adsorption-desorption using a batch equilibrium method. DOI :10.1787/9789264069602-en

Oka, H., Y. Ito, and H. Matsumoto. 2000. Chromatographic analysis of tetracycline antibiotics in foods. J. Chromatogr. A, 882:109-133.

Overdevest, I., I. Willemsen, M. Rijnsburger, A. Eustace, L. Xu, P. Hawkey, M. Heck, P. Savelkoul, C. Vandenbroucke-Grauls, K. van der Zwaluw, X. Huijsdens, and J. Kluytmans. 2011. Extendedspectrum $\beta$-lactamase genes of Escherichia coli in chicken meat and humans, The Netherlands. Emerg. Infect. Dis., 17(7):1216-22.

Pan, X., Z. Qiang, W. Ben, and M. Chen. 2011. Residual veterinary antibiotics in swine manure from concentrated animal feeding operations in Shandong Province, China. Chemosphere, 84(5): 695-700.

Picó, Y., and V. Andreu. 2007. Fluoroquinolones in soil-risks and challenges. Anal. Bioanal. Chem., 387:1287-1299.

Pomati, F., A.G. Netting, D. Calamari, and B.A. Neilan. 2004. Effects of erythromycin, tetracycline and ibuprofen on the growth of Synechocystis sp. and Lemna minor. Aquat. Toxicol., 67:387-396.

Price, L.B., L.G. Lackey, R. Vailes, and E. Silbergeld. 2007. The persistence of fluoroquinoloneresistant Campylobacter in poultry production. Environ. Health Perspect., 115(7):1035-9.

Rabølle, M., and N.H. Spliid. 2000. Sorption and mobility of metronidazole, olaquindox, oxytetracycline and tylosin in soil. Chemosphere, 40(7):715-22. 
Reuland, E.A., N. Al Naiemi, S.A. Raadsen, P.H. Savelkoul, J.A. Kluytmans, and C.M. VandenbrouckeGraul. 2014. Prevalence of ESBL-producing Enterobacteriaceae in raw vegetables. Eur. J. Clin. Microbiol. Infect. Dis., 33(10):1843-6.

Resende, J.A., V.L. Silva, T.L. de Oliveira, S. de Oliveira Fortunato, J. da Costa Carneiro, M.H. Otenio, and C.G. Diniz. 2014. Prevalence and persistence of potentially pathogenic and antibiotic resistant bacteria during anaerobic digestion treatment of cattle manure. Bioresource Technol., 153:284-91.

Rice, E.W., J.W. Messer, C.H. Johnson, and D.J. Reaoner. 1995. Occurrence of high-level aminoglycoside resistance in environmental isolates of Enterococci. Appl. Environm. Microbiol., 61: 374-376

Salvatore, M.J., and S.E. Katz. 1993. Solubility of antibiotics used in animal feeds in selected solvents. J. AOAC Int., 76:952-956.

Sarmah, A.K., M.T. Meyer, and A.B.A. Boxall. 2006. A global perspective on the use, sales, exposure pathways, occurrence, fate and effects of veterinary antibiotics (VAs) in the environment. Chemosphere, 65(5): 725-759.

Sassman, S.A., A.K. Sarmah, and L.S. Lee. 2007. Sorption of tylosin A, D, and A-aldol and degradation of tylosin A in soils. Environ. Toxicol. Chem., 26(8):1629-35.

Sassman, S.A., and L.S. Lee. 2005. Sorption of three tetracyclines by several soils: assessing the role of $\mathrm{pH}$ and cation exchange. Environ. Sci. Technol., 39:7452-7459.

Schwarz, S., and E. Chaslus-Dancla. 2001. Use of antimicrobials in veterinary medicine and mechanisms of resistance. Vet. Res., 32(3-4): 201-225.

Selvam, A., D. Xu, Z. Zhao, and J.W. Wong. 2012. Fate of tetracycline, sulfonamide and fluoroquinolone resistant genes and the changes in bacterial diversity during composting of swine manure. Bioresource Technol.,126:383-90.

Seppälä, H., T. Klaukka, J. Vuopio-Varkila, A. Muotiala, H. Helenius, K. Lager, and P. Huovinen. 1997. The effect of changes in the consumption of macrolide antibiotics on erythromycin resistance in Group A streptococci in Finland. New England J. Med. 337(7): 441-446.

Silveira, E., A.R. Freitas, P. Antunes, M. Barros, J. Campos, T.M. Coque, L. Peixe, and C. Novais. 2014. Co-transfer of resistance to high concentrations of copper and first-line antibiotics among Enterococcus from different origins (humans, animals, the environment and foods) and clonal lineages. J. Antimicrob. Chemother., 69(4):899-906.

Speksnijder, D.C., D.J. Mevius, C.J. Bruschke, and J.A. Wagenaar. 2015. Reduction of veterinary antimicrobial use in the Netherlands. The Dutch success model. Zoonoses Public Health, 62, Suppl $1: 79-87$.

Storteboom, H.N., S.-C. Kim, K.C. Doesken, K.H. Carlson, J.G. Davis, and A. Pruden. 2007. Response of antibiotics and resistant genes to high-intensity and low-intensity manure management. Environ. Qual., 36:1695-1703.

Subbiah, M., S.M. Mitchell, J.L. Ullman, and D.R. Call. 2011. $\beta$-Lactams and florfenicol antibiotics remain bioactive in soils while ciprofloxacin, neomycin, and tetracycline are neutralized. Appl. Environ. Microbiol., 77(20): 7255-7260.

Subbiah, M., D.H. Shah, T.E. Besser, J.L. Ullman, and D.R. Call. 2012. Urine from treated cattle drives selection for cephalosporin resistant Escherichia coli in soil. PLoS ONE 7(11): e48919.

Sukul, P., and M. Spiteller. 2006. Sulfonamides in the environment as veterinary drugs. Rev. Environ. Contam. Toxicol., 187:67-101.

Sukul, P., and M. Spiteller. 2007. Fluoroquinolone antibiotics in the environment. Rev. Environ. Contam. Toxicol.,191:131-62.

Sukul, P., M. Lamshöft, S. Zühlke, and M. Spiteller. 2008. Sorption and desorption of sulfadiazine in soil and soil-manure systems. Chemosphere, 73(8):1344-1350.

Ternes, T.A. 2001. Analytical methods for the determination of pharmaceuticals in aqueous environmental samples. TRAC, 20:419-434.

Tham, J., M. Walder, E. Melander, and I. Odenholt. 2012. Prevalence of extended-spectrum betalactamase-producing bacteria in food. Infect. Drug Resist. 5:143-7.

Thiele-Bruhn, S. 2003. Pharmaceutical antibiotic compounds in soils-a review. J. Plant Nutr. Soil Sci., 166:145-167.

Thiele-Bruhn, S., and I.-C.Beck. 2005. Effects of sulfonamide and tetracycline antibiotics on soil microbial activity and microbial biomass. Chemosphere, 59(4):457-465.

Thiele-Bruhn, S., and D. Peters. 2007. Photodegradation of pharmaceutical antibiotics on slurry and soil surfaces. Landbauforschung Völkenrode 1(57):13-23. 
Thuy, H.T., P. Nga, and T.T. Loan. 2011. Antibiotic contaminants in coastal wetlands from Vietnamese shrimp farming. Environ. Sci. Pollut. Res. Int., 18(6):835-41.

Tolls, J. 2001. Sorption of veterinary pharmaceuticals in soils: A review. Environ. Sci. Technol. 35(17): 3397-3406.

Torniainen, K., S. Tammilehto, and V. Ulvi. 1996. The effect of pH, buffer type and drug concentration on the photodegradation of ciprofloxacin. Int. J. Pharmaceutics, 132(1): 53-61.

Toutain, P.-L., A. Ferran, and A. Bousquet-Me'lou. 2010. Species differences in pharmacokinetics and pharmacodynamics. In: Comparative and Veterinary Pharmacology, Handbook of Experimental Pharmacology 199, F. Cunningham et al. (eds.) Springer-Verlag Berlin Heidelberg, DOI 10.1007/978-3-642-10324-7_2.

Tuan, X.L., and Y. Munekage. 2004. Residues of selected antibiotics in water and mud from shrimp ponds in mangrove areas in Vietnam. Mar. Pollut. Bull., 49:922-929.

Udikovic-Kolic, N., F. Wichmann, N.A. Broderick, and J. Handelsman. 2014. Bloom of resident antibiotic-resistant bacteria in soil following manure fertilization. Proc. Natl. Acad. Sci. USA.,111(42):15202-7.

Valverde, R.S., M.D. Gil García, M.M. Galera, and H.C. Goicoechea. 2006. Determination of tetracyclines in surface water by partial least squares using multivariate calibration transfer to correct the effect of solid phase preconcentration in photochemically induced fluorescence signals. Anal. Chim. Acta, 562: 85-93.

Van Boeckel, T.P., C. Brower, M. Gilbert, B.T. Grenfell, S.A. Levin, T.P. Robinson, A. Teillant, and R. Laxminarayan. 2015. Global trends in antimicrobial use in food animals. Proc. Natl. Acad. Sci. USA, 112 (18): 5649-5654.

Van den Bogaard, A.E., and E.E. Stobberingh. 1999. Antibiotic usage in animals: impact on bacterial resistance and public health. Drugs, 58:589-607.

Volmer, D.A., and J.P.M. Hui. 1998. Study of erythromycin A decomposition products in aqueous solution by solid-phase microextraction/Liquid Chromatography/Tandem Mass Spectrometry. Rapid Commun. Mass Spectrom. 12: 123-129.

Voss, A., F. Loeffen, J. Bakker, C. Klaassen, and M. Wulf. 2005. Methicillin-resistant Staphylococcus aureus in pig farming. Emerg. Infect. Dis., 11(12):1965-6.

Wegst-Uhrich, S.R., D.A.G. Navarro, L. Zimmerman, and D.S. Aga. 2014. Assessing antibiotic sorption in soil: a literature review and new case studies on sulfonamides and macrolides Chem. Central J. $8: 5$.

Wei, R.C., F. Ge, S.Y. Huang, M. Chen, and R. Wang. 2011. Occurrence of veterinary antibiotics in animal wastewater and surface water around farms in Jiangsu Province, China. Chemosphere, 82:1408-1414.

Westergaard, K., A.K. Müllera, S. Christensenb, J. Bloemc, and S.J. Sørensen. 2001. Effect of tylosin as a disturbance on the soil microbial community. Soil Biol. Biochem., 33: 2061-2071.

WHO, 2014. Antimicrobial resistance: global report on surveillance. World Health Organization. Retrieved from http://www.who.int/drugresistance on 19-05-2014.

WHO, 2007. Report of the FAO/WHO/OIE, Expert meeting on critically important antimicrobials. Rome, Italy, 26-30 November 2007. Retrieved from http://www.who.int/foodsafety/publications/antimicrobials/en/

Wulf, M.W., M. Sørum, A. van Nes, R. Skov, W.J. Melchers, C.H. Klaassen, and A. Voss. 2008. Prevalence of methicillin-resistant Staphylococcus aureus among veterinarians: an international study. Clin. Microbiol. Infect. 14(1):29-34.

Winckler, C., and A. Grafe. 2001. Use of veterinary drugs in intensive animal production--evidence for persistence of tetracycline in pig slurry. J. Soils Sediments, 1: 66-70.

Zessel, K., S. Mohring, G. Hamscher, M. Kietzmann, and J. Stahl. 2014. Biocompatibility and antibacterial activity of photolytic products of sulfonamides. Chemosphere, 100:167-174.

Zhang, D.D., L.F. Lin, Z.X. Luo, C.Z. Yan, and X. Zhang. 2011. Occurrence of selected antibiotics in Jiulongjiang River in various seasons, South China. J. Environ. Monit., 13:1953-1960.

Zhao, L., Y.H. Dong, and H. Wang. 2010. Residues of veterinary antibiotics in manures from feedlot livestock in eight provinces of China. Sci. Total Environ., 408(5): 1069-1075.

Zielezny, Y., J. Groeneweg, H. Vereecken, and W. Tappe. 2006. Impact of sulfadiazine and chlorotetracycline on soil bacterial community structure and respiratory activity. Soil Biol. Biochem., 38(8): 2372-2380. 
RIKILT Wageningen UR

\section{P.O. Box 230}

6700 AE Wageningen

The Netherlands

T +31 (0)31748 0256

www.wageningenUR.nl/en/rikilt

RIKILT report 2016.009
RIKILT Wageningen UR is part of the international knowledge organisation Wageningen University \& Research centre. RIKILT conducts independent research into the safety and reliability of food. The institute is specialised in detecting and identifying substances in food and animal feed and determining the functionality and effect of those substances.

The mission of Wageningen UR (University \& Research centre) is 'To explore the potential of nature to improve the quality of life'. Within Wageningen UR, nine specialised research institutes of the DLO Foundation have joined forces with Wageningen University to help answer the most important questions in the domain of healthy food and living environment. With approximately 30 locations, 6,000 members of staff and 9,000 students, Wageningen UR is one of the leading organisations in its domain worldwide. The integral approach to problems and the cooperation between the various disciplines are at the heart of the unique Wageningen Approach. 



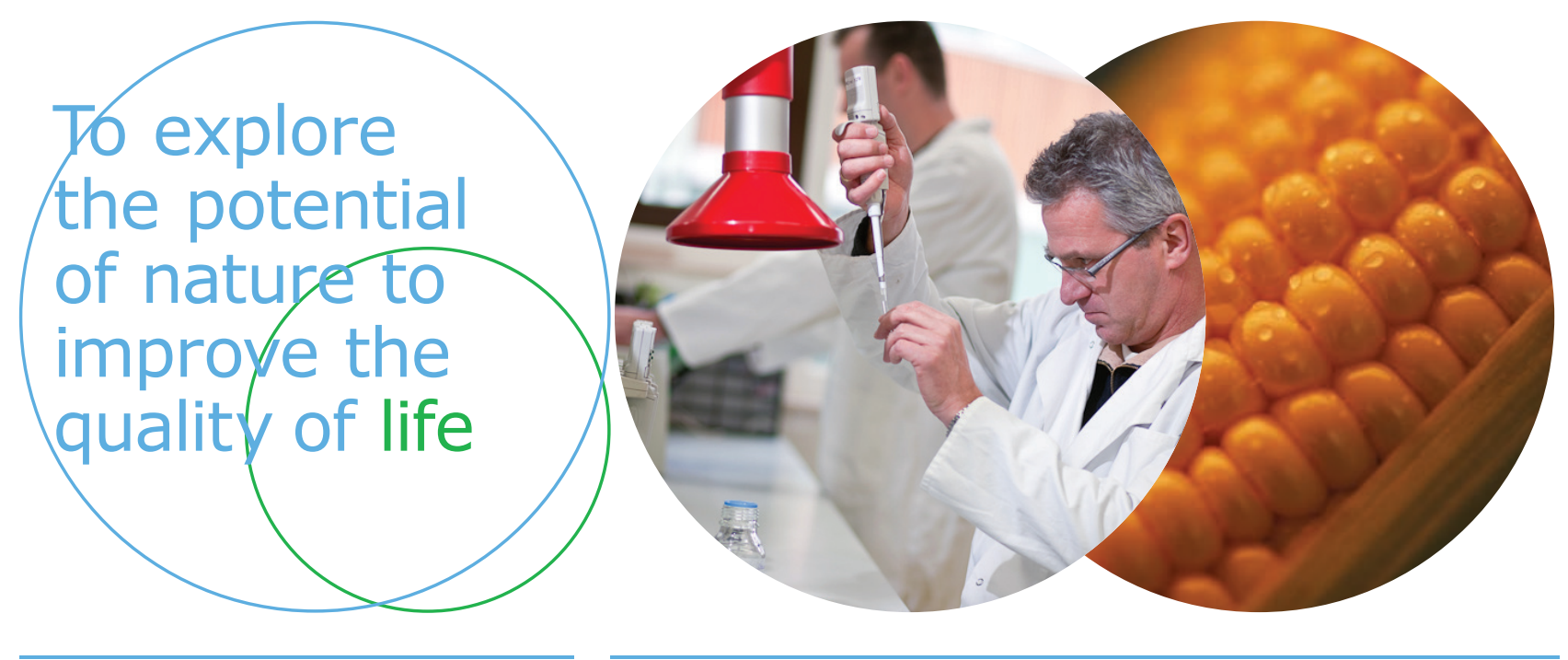

RIKILT Wageningen UR

P.O. Box 230

6700 AE Wageningen

The Netherlands

T +31 (0)317480256

www.wageningenUR.nl/en/rikilt

RIKILT report 2016.009
RIKILT Wageningen UR is part of the international knowledge organisation Wageningen University \& Research centre. RIKILT conducts independent research into the safety and reliability of food. The institute is specialised in detecting and identifying substances in food and animal feed and determining the functionality and effect of those substances.

The mission of Wageningen UR (University \& Research centre) is 'To explore the potential of nature to improve the quality of life'. Within Wageningen UR, nine specialised research institutes of the DLO Foundation have joined forces with Wageningen University to help answer the most important questions in the domain of healthy food and living environment. With approximately 30 locations, 6,000 members of staff and 9,000 students, Wageningen UR is one of the leading organisations in its domain worldwide. The integral approach to problems and the cooperation between the various disciplines are at the heart of the unique Wageningen Approach. 